\title{
ANALISIS IMPLEMENTASI GOVERNMENT FINANCE STATISTICS DI INDONESIA: PENDEKATAN TEORI INSTITUSIONAL
}

\author{
Nur Istiqomah \\ Direktorat Akuntansi dan Pelaporan Keuangan \\ Alamat Korespondensi: astrasima@gmail.com
}

\section{INFORMASI ARTIKEL}

Diterima Pertama

05 Mei 2017

Dinyatakan Diterima

30 Juli 2018

\section{KATA KUNCI:}

Government Finance Statistics, Teori Institusional, Kebijakan Fiskal, Isomorphism, Organisasi, Keuangan Pemerintah.

\section{KLASIFIKASI JEL:}

E14, H5

\begin{abstract}
Implementation Governmet Finance Statistics in Indonesia is one of the organization's response to the mandate of Law No. 1 year of 2004. As stipulated by that, the Government Financial Statements that is prepared can produce financial statistik. One of the function of the Government Finance Statistics is to analyze and evaluate fiscal policy. DJPB as an organization that compile report as a constituent of the government's financial statements need to respond to this implementation. To realize the implementation of the Government Finance Statistics, organizations affected by the environment in which is located, so that the organization strives to be similar to the environment that is called isomorphism. Isomorphism occurred because of institutional pressures that influence organizational decision making. This study aims to determine the institutional pressures that affect decision making in impelemntasi GFS in Indonesia. The institutional pressure is divided of three to coersive pressure, mimetic pressure and normative pressure. The methodology used in this study is qualitative methods with intrepretatif techniques through institutional theory approach. The results of this study concluded that the organization experience symptoms that responded isomorphism according to the kind of pressure that appears. So that the organization mapped the pressures that affect the decision making of implementation GFS in Indonesia that have appropriate expectations for the purpose of analysis and evaluation of fiscal policy in accordance with Law No. 1 of 2004.
\end{abstract}

\section{ABSTRAK}

Implementasi Governmet Finance Statistics di Indonesia merupakan salah satu langkah organisasi dalam merespon amanat Undang-Undang No. 1 Tahun 2004. Sesuai amanat undang-undang tersebut bahwa laporan keuangan Pemerintah yang disusun dapat menghasilkan statistik keuangan. Salah satu fungsi Government Finance Statistics adalah untuk menganalisis dan mengevaluasi kebijakan fiskal. Direktorat Jenderal Perbendaharaan sebagai organisasi yang melakukan tugasnya sebagai penyusun laporan keuangan pemerintah perlu merespon implementasi ini. Untuk mewujudkan implementasi Government Finance Statistics, organisasi dipengaruhi oleh lingkungan di mana berada, sehingga organisasi berupaya menjadi mirip dengan lingkungannya inilah yang disebut dengan isomorphism. Di Maggio et al (1983) dalam Amirya et al (2012). Isomorphism terjadi karena adanya tekanan-tekanan institusional yang memengaruhi pengambilan keputusan dalam organisasi. Penelitian ini bertujuan untuk mengetahui tekanan-tekanan institusional yang memengaruhi pengambilan keputusan dalam implementasi GFS di Indonesia. Tekanan tersebut dibagi tiga menjadi coersive pressure, mimetic pressure dan normative pressure. Metodologi yang digunakan dalam penelitian ini menggunakan metode kualitatif dengan teknik intrepretatif melalui pendekatan teori institusional. Hasil penelitian ini menyimpulkan bahwa organisasi DJPb mengalami gejala-gejala isomorphism yang direspon akibat tekanan yang muncul. Organisasi menjadi terpetakan akan tekanan-tekanan yang mempengaruhi dalam pengambilan keputusan implementasi GFS di Indonesia yang menjadi latar belakang implementasi GFS yang belum sesuai ekpektasi untuk tujuan analisis dan evaluasi kebijakan fiskal sesuai dengan UndangUndang No 1 Tahun 2004. Implementasi GFS dilaksanakan untuk pemenuhan tujuan lain akibat jenis tekanan institusional tertentu yang mendominasi. 


\section{PENDAHULUAN}

Penjelasan Undang- Undang Nomor 1 Tahun
2004 tentang Perbendaharaan Negara mengamanatkan bahwa laporan keuangan pemerintah dapat menghasilkan statistik keuangan. Statistik keuangan tersebut mengacu kepada manual Government Finance Statistics (GFS) sehingga dapat memenuhi kebutuhan analisis kebijakan dan kondisi fiskal, pengelolaan dan analisis perbandingan antar negara (cross country studies), kegiatan pemerintahan, dan penyajian statistik keuangan pemerintah. Penyusunan Laporan Government Finance Statistics merupakan salah satu upaya untuk mewujudkan transparansi dan akuntabilitas dalam pengelolaan keuangan negara.

Sejak penerapan Government Finance Statistics tahun 2011 sampai dengan tahun 2014, basis akuntansi yang digunakan dalam penyusunan laporan keuangan pemerintah adalah basis akuntansi Cash Towards Accrual. Sedangkan Laporan Government Finance Statistics menggunakan basis akuntansi akrual dalam penyusunannya. Basis akuntansi akrual baru diberlakukan pada tahun pelaporan 2015 di Indonesia. Selain itu, sejak reformasi pengelolaan keuangan negara digulirkan, pemerintah telah melakukan upaya-upaya penyusunan Laporan Government Finance Statistics meskipun laporan tersebut masih bersifat parsial dan belum terintegrasi dengan Sistem Akuntansi Pemerintahan. Penyusunan Laporan Government Finance Statistics dan proses mapping akun dilakukan secara manual menggunakan microsoft excel. Sedangkan statistik keuangan pemerintah adalah "sebuah sistem pengumpulan data statistik keuangan mengenai kegiatan pemerintahan yang berhubungan dengan transaksi-transaksi keuangan negara, dalam format yang sesuai untuk analisa ekonomi dan dapat diterima secara internasional". (Nasution, 2004).

Sistem Government Finance Statistics merupakan suatu sistem pelaporan yang menghasilkan data yang komprehensif atas aktivitas ekonomi dan keuangan pemerintah. Selain itu juga menghasilkan data sektor publik yang dilaksanakan dengan mengacu pada Manual Statistik Keuangan Pemerintah Indonesia. Dengan demikian, data statistik keuangan pemerintah dapat digunakan untuk menganalisis dan mengevaluasi kebijakan fiskal, khususnya kinerja sektor pemerintah umum dan sektor publik.

Pada awalnya, kebijakan fiskal hanya mengarah pada situasi bagaimana menghadapi masalah pengangguran. Setelah Perang Dunia II kebijakan fiskal digunakan untuk mengatasi keadaan inflasi. Dalam kebijakan fiskal terkandung anggapan yang pasti bahwa sebenarnya rumah tangga negara atau pemerintah tidak dapat disamakan dengan para individu dan pengaruhnya dari tindakan masing-masing terhadap keseluruhan masyarakat (Suparmoko, 1986).

Secara umum, kebijakan fiskal bertujuan untuk memelihara stabilitas ekonomi. Dengan demikian, pendapatan nasional secara nyata terus meningkat. Peningkatan tersebut sesuai dengan penggunaan sumber daya faktor-faktor produksi dan efektivitas kegiatan masyarakat. Penggunaan sumber daya tersebut tidak mengabaikan redistribusi pendapatan atau kekayaan dan upaya kesempatan kerja. Guna memelihara stabilitas ekonomi tersebut, maka digunakan Government Finance Statistics sebagai salah satu alat analisis kebijakan fiskal. Penerapan Government Finance Statistics di negara-negara yang telah menggunakannya sebagai analisis dan evaluasi kebijakan fiskal dapat membantu mengoptimalkan jalan keluar permasalahan ekonomi suatu negara.

Penelitian yang dilakukan Jaruphan Wanitthanankun, (2014) menyimpulkan bahwa pemerintahan memenuhi syarat Fiscal Transparancy Code dalam berbagai aspek dan melebihi kriteria dalam beberapa hal, indeks analisis, dan manajemen risiko fiskal berada di bawah ukuran dasar. Adapun dampak fiskal atas perubahan yang mungkin terjadi dalam variabel ekonomi makro, utang pemerintah eksplisit secara hukum maupun perjanjian, dan utang implisit yang mungkin menjadi beban bagi pemerintah, harus ditelusuri, dievaluasi, serta diawasi secara ketat.

Government Finance Statistics yang telah diterapkan di Indonesia memerlukan respon dari Pemerintah Indonesia. Pemerintah Indonesia dalam hal ini adalah Kementerian Keuangan melalui Direktorat Jenderal Perbendaharaan sebagai organisasi eselon I. Carruthers (1995) dalam Amirya et al (2012) mengatakan bahwa "suatu organisasi dalam studi ahli institusionalisme menyatakan bahwa institusionalisme berkaitan dengan struktur organisasi yang dipengaruhi oleh lingkungan sosial di mana berada." Meyer dan Rowan (1977, 53) dalam Amirya et al (2012) mengatakan "kesuksesan organisasi bergantung pada faktor-faktor lain (terutama legitimasi) selain koordinasi yang efisien dan pengendalian kegiatan produktif." Djamhuri (2009) dalam Amirya et al (2012) mengemukakan "guna memperoleh legitimasi, sebuah organisasi berupaya untuk melembagakan unsur-unsur lingkungan (ide, logika, praktik, teknik dan kebiasaan) ke dalam organisasi, sehingga unsur-unsur lingkungan menjadi bagian dari lembaga organisasi tersebut." Salah satunya, organisasi berupaya menjadi mirip (isomorphism) dengan lingkungan kelembagaan.

Peristiwa isomorphism terjadi karena adanya tekanan-tekanan institusional yang mempengaruhi pengambilan keputusan organisasi dalam pengimplementasian Government Finance Statistics di Indonesia. Tekanan instistusional yang melingkupi organisasi terdapat dalam lingkungan 
yang berperan sebagai dasar adanya pengambilan keputusan. Mengingat pentingnya Government Finance Statistics untuk analisis dan evaluasi kebijakan fiskal bagi keberlangsungan ekonomi di Indonesia, maka pemerintah harus benar-benar mengimplementasikannya. Direktorat Jenderal Perbendaharaan sebagai organisasi ingin penulis teliti dalam proses pengimplementasian Government Finance Statistics dari pendekatan Teori Institusional-isomorphism. Tekanan-tekanan institusional-isomorphism menurut Di Maggio et al (1983) yang dibagi menjadi tiga yaitu coersive, mimetic, dan normative, yang mempengaruhi pengambilan kebijakan dalam implementasi Government Finance Statistics di Indonesia menjadi pertanyaan dalam penelitian ini.

Tujuan dari penelitian ini adalah untuk mengetahui tekanan-tekanan institusional dalam implementasi Government Finance Statistics. Tujuan implementasi Government Finance Statistics secara khusus yang digunakan untuk analisis dan evaluasi kebijakan fiskal. Selain itu, tujuan penelitian ini juga sebagai tambahan literature penelitian yang bersifat multidisiplin terkait institusi dan Government Finance Statistics.

Penelitian ini diharapkan mampu memberikan kontribusi berupa saran-saran perbaikan dan pengembangan implementasi Government Finance Statistics secara komprehensif. Implementasi Government Finance Statistics juga diharapkan sesuai dengan salah satu tujuannya sebagai analisis dan evaluasi kebijakan fiskal secara umum di Indonesia.

\section{KERANGKA TEORI}

\subsection{Government Finance Statistics}

Statistik keuangan pemerintah adalah "sebuah sistem pengumpulan data statistik keuangan mengenai kegiatan pemerintahan yang berhubungan dengan transaksi-transaksi keuangan negara, dalam format yang sesuai untuk analisa ekonomi dan dapat diterima secara internasional". (Nasution, 2004). Statistik keuangan pemerintah menghasilkan jembatan untuk menerjemahkan informasi akuntansi ke dalam bahasa yang lebih dimengerti dan sejalan dengan sistem statistik makro ekonomi yang digunakan dalam ekonomi dan statistik.

Menurut Organization for Economic Cooperation and Development (OECD), statistik keuangan pemerintah adalah "an accounting framework developed by the International Monetary Fund to provide guidelines for the compilation of fiscal accounts". Dalam penerapan statistik keuangan pemerintah yang disebut juga Government Finance Statistics digunakan pedoman Government Finance Statistics Manual (GFSM) yang diterbitkan oleh International Monetary Fund. GFSM pertama kali diterbitkan pada tahun 1986 kemudian mengalami revisi sebanyak dua kali pada tahun 2001 dan 2014

Indonesia mengadaptasi GFSM dalam Peraturan Menteri Keuangan Nomor 275/PMK.05/2014 tentang Manual Statistik Keuangan Pemerintah Indonesia. Indonesia mengadaptasi GFSM dan revisinya meliputi penggunaan definisi, cakupan, kerangka analitis, laporan dan indikator utama, serta menyesuaikannya dengan kondisi dan kebutuhan Pemerintah Indonesia. Beberapa pengaturan dalam Manual Statistik Keuangan Pemerintah Indonesia berbeda dengan GFSM 2014. Hal ini antara lain disebabkan perbedaan pengaturan dengan Standar Akuntansi Pemerintahan (SAP) dan sistem akuntansi pemerintah.

Government Finance Statistics (GFS) atau Statistik Keuangan Pemerintah menurut Peraturan Menteri Keuangan Nomor 275/PMK.05/2014 tentang Manual Statistik Keuangan Pemerintah Indonesia didefinisikan sebagai "suatu sistem pelaporan yang menghasilkan data yang komprehensif atas aktivitas ekonomi dan keuangan pemerintah dan sektor publik yang dilaksanakan dengan mengacu pada Manual Statistik Keuangan Pemerintah Indonesia". Tujuan dan kegunaan GFS menurut PMK Nomor 275/PMK.05/2014 antara lain adalah sebagai berikut:

a. Digunakan untuk penyusunan kebijakan fiskal dan analisis perkembangan operasi keuangan, posisi keuangan dan kondisi likuiditas sektor pemerintahan umum atau sektor publik secara konsisten dan sistematis.

b. Sebagai analisis pengaruh kebijakan fiskal terhadap ekonomi, termasuk sumber daya yang digunakan, beban pajak, kondisi keuangan, dan utang nasional.

c. Sebagai analisis fiskal dan sektor publik dan sumbangannya terhadap perekonomian seperti permintaan, investasi dan tabungan agregat.

d. Sebagai analisis efektivitas pengeluaran terhadap pengentasan kemiskinan dan kesinambungan kebijakan fiskal.

Secara garis besar, GFS mencakup sektor pemerintah umum dan korporasi publik yang keduanya diperluas menjadi sektor publik. Sektor pemerintah umum terdiri dari unit pemerintah dan semua non market institusi nirlaba yang dikendalikan dan sebagian besar dibiayai unit pemerintah. Entitas tersebut merupakan residen perekonomian Indonesia dan merupakan unit institusi yang dikendalikan oleh pemerintah atau bagian integral dari unit institusi pemerintah yang mengendalikannya. Selain itu entitas tersebut merupakan produsen non pasar juga bukan merupakan market establishment yang memenuhi definisi unit institusi.

Definisi unit institusi menurut PMK Nomor 275/PMK.05/2014 tentang Manual Statistik 
Keuangan Pemerintah Indonesia adalah sebagai berikut:

Entitas ekonomi yang mempunyai kemampuan untuk memiliki aset, mengambil keputusan ekonomi dan melakukan aktivitas ekonomi dengan tanggung jawab hukum, memunculkan atau mengambil alih kewajiban, melakukan kontrak dan komitmen masa depan, dan melakukan aktivitas/transaksi ekonomi dengan entitas lainnya, serta mempunyai satu set akun yang lengkap, termasuk neraca.

Sektor pemerintah umum terdiri dari pemerintah pusat dan pemerintah daerah. Pemerintah pusat ini terdiri dari empat institusi yaitu Kementerian Negara/Lembaga, Badan Layanan Umum, Dana Jaminan Sosial, dan Lembaga Non Struktural yang dibentuk karena urgensi terhadap suatu tugas khusus tertentu yang tidak dapat diwadahi dalam bentuk kelembagaan pemerintahan atau kelembagaan negara konvensional. Lembaga Non Strutural dapat diklasifikasikan sebagai sektor pemerintah umum jika memenuhi karateristik dalam pengendalian kebijakan maupun pembiayaan.

Sektor korporasi publik menurut PMK Nomor 275/PMK.05/2014 adalah "entitas-entitas yang merupakan residen perekonomian negara, merupakan unit institusi yang dikendalikan oleh pemerintah, dan merupakan produsen pasar." Sektor korporasi publik terdiri dari Badan Usaha Milik Negara/Daerah dan Bank Sentral.

GFS menurut GFSM edisi pertama tahun 1986 yang diterbitkan oleh International Monetary Fund (IMF) berisi uraian atas sistem statistik makro ekonomi, yang dirancang untuk mendukung analisis fiskal suatu negara. Sistem GFS menggunakan prinsip-prinsip akuntansi dan ekonomi dalam mengkompilasi data statistik dan mempresentasikan data fiskal dalam kerangka kerja analitis yang mencakup pos-pos penyeimbang yang tepat.

Dalam penyusunan Laporan GFS Indonesia, mengacu pada Manual Statistik Keuangan Pemerintah Indonesia yang menurut PMK Nomor 275/PMK.05/2014 didefinisikan sebagai berikut:

Manual dan pedoman yang menyediakan kerangka konseptual dan pelaporan untuk menghasilkan data yang komprehensif atas aktivitas ekonomi dan keuangan pemerintah yang sejalan dengan standar internasional yang digunakan dalam menyusun laporan ekonomi dan statistik seperti Sistem Neraca Nasional (System of National Accounts - SNA), Manual Neraca Pembayaran (The Balance of Payments Manual), dan Manual Statistik Moneter dan Keuangan(The Monetary and Financial Statistics Manual), sebagai acuan dalam melaksanakan Statistik Keuangan Pemerintah, sehingga data Statistik Keuangan Pemerintah dapat digunakan untuk menganalisis dan mengevaluasi kebijakan fiskal, khususnya kinerja sektor pemerintah umum dan sektor publik.

Output penerapan GFS di Indonesia adalah Laporan Statistik Keuangan Pemerintah yang selanjutnya disingkat LSKP. Menurut PMK Nomor 275/PMK.05/2014 LSKP adalah "laporan yang disusun dalam rangka pengambilan kebijakan fiskal dan makro ekonomi selama suatu periode berdasarkan klasifikasi Statistik Keuangan Pemerintah. LSKP inilah nantinya yang menjadi alat untuk menganalisis dan mengevaluasi kebijakan fiskal Indonesia."

Laporan Statistik Keuangan Pemerintah menjawab kebutuhan perlunya konsolidasi fiskal dan statistik keuangan pemerintah secara nasional. Konsolidasi fiskal dan statistik keuangan pemerintah bermanfaat dalam menyediakan informasi fiskal dan keuangan yang lebih komprehensif dan andal bagi pengambil kebijakan, memberikan gambaran yang lebih komprehensif mengenai aktivitas pemerintahan, dan untuk menilai kinerja fiskal pemerintah.

\subsection{Teori Institusional}

Teori institusional berhubungan dengan struktur sosial. "Teori institusional memperlihatkan bagaimana struktur seperti skema, aturan, norma, dan rutin menjadi bentuk yang bersifat otoritatif untuk terjadinya perilaku sosial", (Scott, 2004, dalam Darono, 2013, 31). Jadi dalam hal ini institusi bukan saja meliputi aturan, nilai, kebiasaan tertentu namun juga harus dilihat adanya tindakan yang terjadi dan bagaimana tindakan itu diulang atau direproduksi.

"Teori institusional dalam studi organisasi dilengkapi dengan konsep isomorphism". (DiMaggio et al. 1983). Dalam hal ini dijelaskan bahwa unit analisis dalam teori institusional adalah organization field yaitu sekelompok organisasi yang secara keseluruhan membentuk suatu kehidupan institusional yang terdiri dari pemasok utama, pelanggan, regulator atau pesaing. Kemudian, organisasi selalu ingin atau dituntut untuk menyesuaikan diri dengan lingkungannya. Proses ini disebut dengan isomorphism, yaitu suatu proses yang mengakibatkan suatu unit dalam organization field menirukan tindakan unit lain sehingga unit tersebut berada dalam situasi yang kurang lebih serupa. Isomorphism berkaitan dengan institusionalisasi. Institusionalisasi adalah proses yang berkelanjutan. Sejalan dengan kondisi ini, maka terjadi proses institusionalisasi, deinstitusionalisasi atau reinstitusionalisasi (Djamhuri et al, 2006).

Secara alamiah, status institusionalisasi hanya bersifat sementara karena organisasi kembali mendapatkan tekanan untuk melakukan institusionalisasi sesuai dengan tuntutan perubahan yang ada. Jadi proses isomorphism itu bersifat gradual. Isomorphism muncul akibat dari adanya berbagai tekanan institusional 
(institutional pressures). Selanjutnya, tekanan institusional menurut DiMaggio et al. (1983) dapat dikelompokkan menjadi tiga yaitu:

\subsubsection{Tekanan koersif (coercive pressures)}

Tekanan koersif menyebabkan isomorphism yang merupakan proses penyesuaian menuju kesamaan dengan cara pemaksaan. Tekanan datang dari pengaruh politik dan masalah legitimasi. Misalnya, tekanan resmi datang dari peraturan pemerintah dan organisasi yang lebih tinggi agar bisa diakui.

\subsubsection{Tekanan normatif (normative pressures)}

Tekanan normatif sering diasosiasikan dengan profesionalisasi yang muncul di bidang tertentu. Norma atau sesuatu yang tepat bagi organisasi berasal dari pendidikan formal dan sosialisasi pengetahuan formal itu di bidang tertentu yang menyokong dan menyebarkan kepercayaan normatif itu. Ketika profesionalisme meningkat maka tekanan normatif juga meningkat.

\subsubsection{Tekanan mimetik (mimetic pressure)}

Tekanan mimetik menyebabkan isomorphism yang merupakan proses di mana organisasi meniru organisasi lain yang berhasil dalam satu bidang, meskipun orgaisasi peniru tidak tahu persis mengapa mereka meniru, bukan karena dorongan supaya lebih efisien.

Dalam kajian institusional terdapat adanya istilah logika institusional. Logika institusional merupakan "suatu konstruksi sosial dari berbagai pola yang berkaitan dengan praktik, asumsi, nilai, keyakinan dan aturan di mana para individu memproduksi dan mereproduksi hal-hal yang nyata, mengorganisasikannya dalam ruang dan waktu, dan menyajikannya menjadi suatu makna dalam realitas sosial" (Thornton et al, 2008). Logika institusional merupakan penghubung antara agen individu dengan praktik-praktik dan struktur aturan institusional. Logika institutional menjadikan para aktor dalam organisasi berperilaku dengan menggunakan pertimbangan rasional.

Pemikir lainnya, John W. Meyer dan Brian Rowan (1977) dalam Amirya et al (2012) memaparkan bahwa "banyak posisi, kebijakan, program dan prosedur organisasi modern dipengaruhi oleh opini publik, pandangan konstituen, pengetahuan sah melalui sistem pendidikan, prestise sosial, hukum, dan pengadilan". Jadi menurut pandangan tersebut pada intinya menjelaskan bahwa perilaku organisasi atau keputusan yang diambil oleh organisasi dipengaruhi oleh institusi yang ada di luar organisasi. Organisasi berupaya untuk menyesuaikan diri dengan tekanan dari luar untuk mempertahankan eksistensinya. Di Maggio et al (1983) berargumen bahwa "teori institusional mengkritik teori ekonomi dan kontingensi yang sangat rasional, yaitu menjelaskan struktur dan fungsi organisasi dengan ukuran efisiensi." Teori itu mengabaikan kekuatan di luar organisasi yang non rasional seperti negara, norma-norma sosial, tradisi, konvensi, yang membentuk organisasi itu.

Scott (2001) mengatakan bahwa "institusi berada pada lingkup struktur sosial, memiliki elemen-elemen simbolis, aktifitas-aktifitas sosial, dan sumber daya material." Keberadaan institusi diperlukan sebagai seperangkat proses yang dicirikan dengan elemen-elemen regulatif, normatif, dan kultural-kognitif yang sarat dengan perubahan. Meskipun unsur-unsur utama dari institusi adalah rules, norms, and cultural benefit, konsep institusi juga menyangkut asosiasi perilaku dan sumber daya material. Dengan demikian pengertian institusi ditentukan oleh batasan legal, prosedural, moral dan kultural yang memiliki legitimasi. Tidak hanya menyangkut property or social order, tetapi juga sebagai proses institusionalisasi maupun deinstitusionalisasi.

Adanya faktor tekanan dari luar tersebut menjadi sebuah kontrol terhadap akses para aktor ke berbagai sumber daya, institusi atau pranata, yang mempengaruhi kinerja dengan berbagai cara. Sehingga bisa disimpulkan bahwa institusi adalah batasan yang diciptakan oleh sebuah sistem sosial yang memiliki kekuatan untuk mengontrol dan mengarahkan interaksi antar manusia melalui aturan formal seperti hukum dan undang-undang maupun informal seperti budaya, tradisi, dan norma di mana berlakunya akan bergantung pada kondisi sosial yang ada.

\section{METODOLOGI PENELITIAN}

\subsection{Metode Kualitatif}

Metode yang digunakan dalam tulisan ini adalah metode kualitatif - naratif (analisis nonhipotesis) yang dimulai dengan asumsi dan penafsiran/teoretis yang membentuk atau mempengaruhi studi tentang permasalahan riset yang terkait dengan makna yang dikenakan oleh individu atau kelompok pada suatu permasalahan sosial atau manusia (Creswell, 2014). Metode kualitatif dalam tulisan ini merupakan metode kualitatif non studi kasus karena penelitian ini tidak menggunakan kasus spesifik tetapi lebih kepada peristiwa secara umum. Penulis menggunakan metode kualitatif karena dalam penelitian yang dilakukan lebih memenuhi karakteristik penelitian kualitatif. Karakteristik kualitatif tersebut menurut Bogdan dan Biklen (1982) dalam Sugiyono (2014) adalah bersifat deskriptif dan data yang terkumpul berbentuk kata-kata atau gambar, sehingga tidak menekankan pada angka tetapi lebih menekankan makna atau data dibalik yang teramati.

Penelitian kualitatif ini lebih menekankan istilah transferability dibandingkan generalizability. Artinya, sejauh mana temuan dari suatu penelitian 
tertentu dapat ditransfer ke setting (situasi) lain. Pendekatan yang digunakan adalah dengan pendekatan teori institusional. Penelitian ini merupakan penelitian multiparadigma, yaitu penelitan yang terkait beberapa disiplin ilmu. Mengidentifikasi tekanan-tekanan institusional dalam organisasi yang berupa pengembangan suatu kerangka kerja yang diharapkan dapat digunakan ke setting organisasi yang berbeda. Kerangka kerja ini utamanya diharapkan dapat digunakan untuk mengidentifikasi dan merespon berbagai tekanan institusional yang muncul dalam implementasi Government Finance Statistics. Adapun kerangka berpikirnya adalah seperti pada Gambar III.1 dan Gambar III.2. Gambar III.1 menunjukkan langkah awal dalam mengidentifikasi tekanan-tekanan institusional yang melingkupi implementasi Government Finance Statistics di Indonesia.

Gambar III.1 Alur Identifikasi Tekanan Institusional

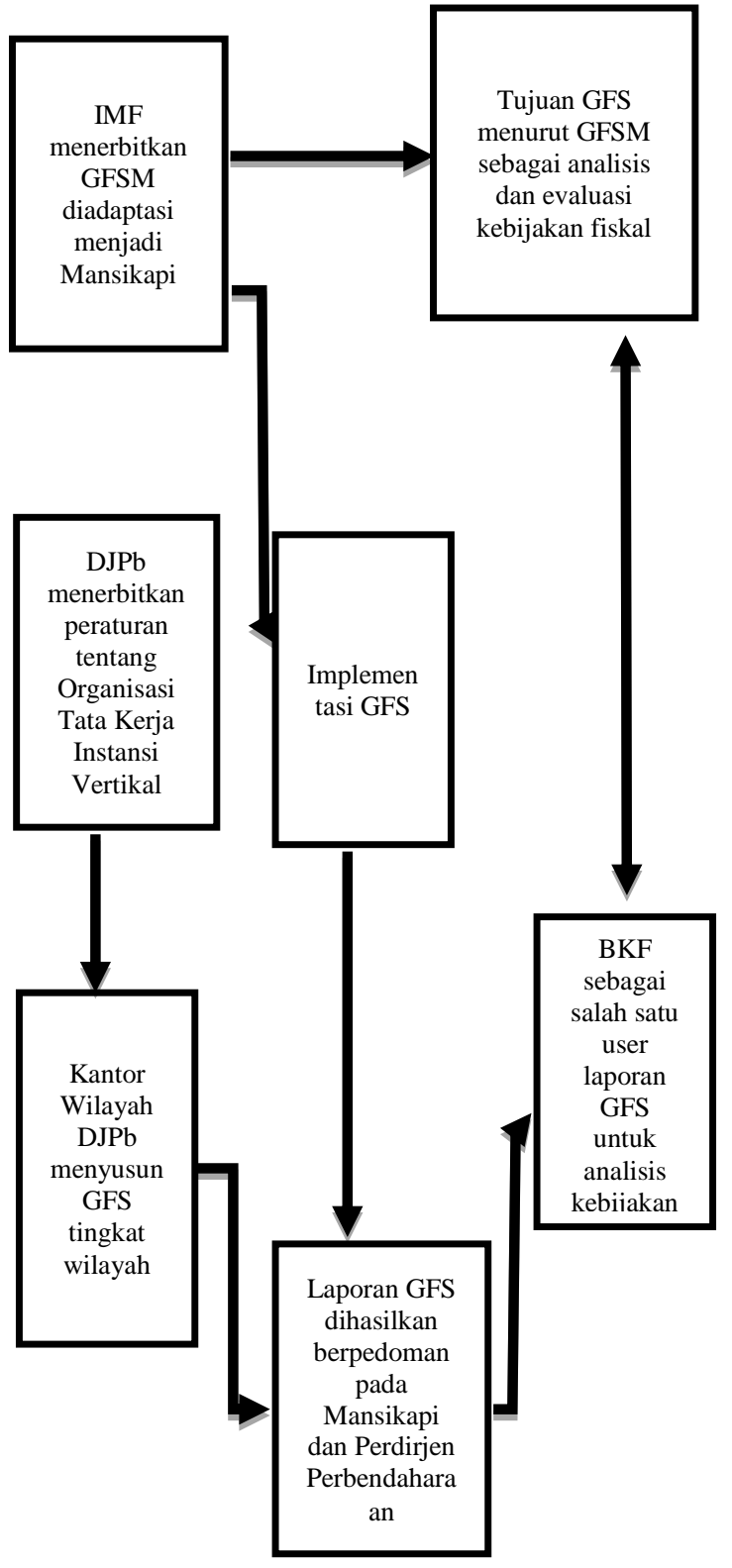

Gambar III.2 Menentukan Jenis Tekanan Institusional

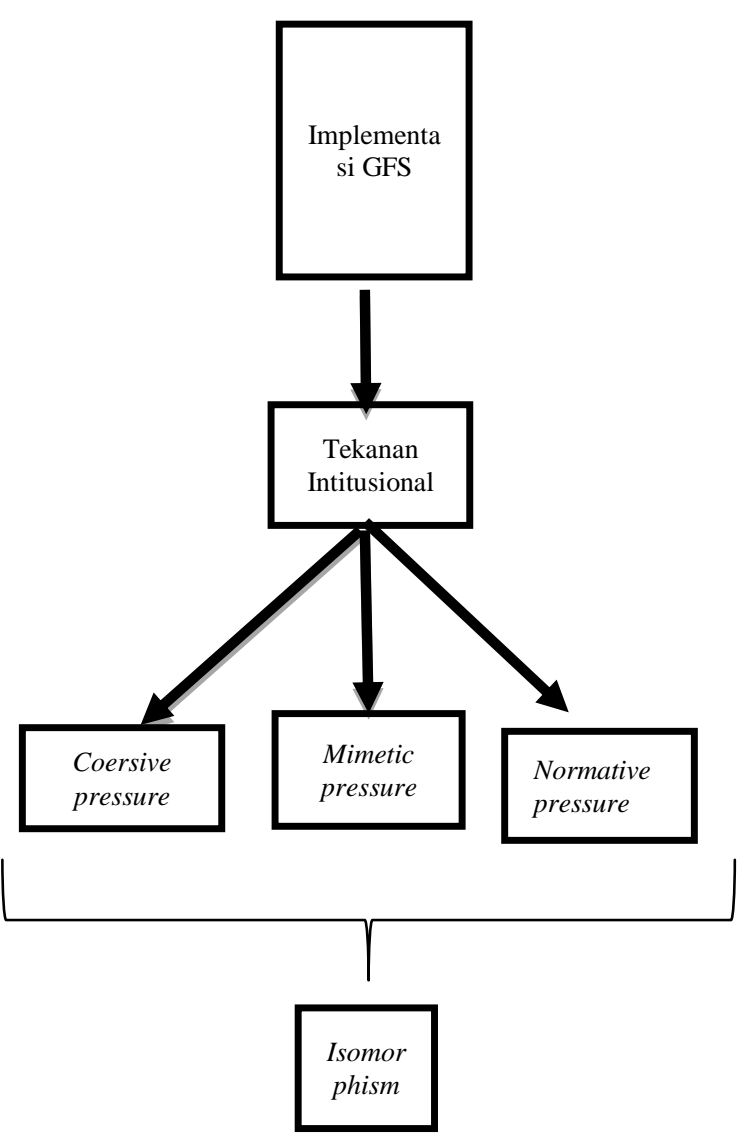

\subsection{Teknik Pengumpulan Data}

Dalam penelitian ini penulis menggunakan data sekunder. Data sekunder berupa jurnal, buku, peraturan, dan literatur lain yang terkait dengan objek penelitian. Untuk mendukung data tersebut, dalam penelitian ini juga dilakukan wawancara kepada pihak-pihak terkait. Teknik pengumpulan data dilakukan dengan dua cara yaitu:

\subsubsection{Teknik Dokumentasi dan Kepustakaan (Library Research)}

Teknik dokumentasi berupa pengumpulan data melalui intrepretasi dokumen-dokumen tertulis. Intrepretasi ini dilakukan dengan membaca dan menganalisis informasi pelaksanaan implementasi Government Finance Statistics berupa laporan-laporan yang telah diterbitkan, data-data fisik maupun elektronik yang tersedia, artikelartikel, peraturan perundang-undangan, dan berbagai sumber lain. Dari dokumen-dokumen yang diterbitkan diidentifikasi berdasarkan sumber perolehan data.

\subsubsection{Teknik wawancara kepada informan (Interview Research)}

Informan dalam penelitian ini berasal dari pihak-pihak yang terjun langsung atau praktisi di lapangan dan terkait langsung dengan objek yang diobservasi. Wawancara dilakukan dengan tanya 
jawab langsung tentang implementasi Government Finance Statistics di Indonesia. Wawancara dilakukan berpedoman pada pertanyaan yang telah disiapkan oleh peneliti dan bersifat semi terstruktur, dan tidak menutup kemungkinan dalam pelaksanaan di lapangan peneliti mengajukan pertanyaan-pertanyaan baru yang terkait dengan permasalahan yang diteliti jika diperlukan. Potensial informan yang berkenan terlibat dalam penelitian ini diuraikan dalam Tabel III.1.

Tabel III.1. Informan Penelitian

\begin{tabular}{|c|c|c|c|}
\hline $\begin{array}{l}\text { Jabatan } \\
\text { Informan dan } \\
\text { Instansi }\end{array}$ & $\frac{\text { Kapasitas }}{\text { Peran }}$ & $\frac{\text { Kode }}{\text { Identifikasi }}$ & $\begin{array}{l}\text { Ekspektasi } \\
\text { Informasi }\end{array}$ \\
\hline $\begin{array}{l}\text { Kepala } \\
\text { Subbagian } \\
\text { Pengembangan } \\
\text { Organisasi, DJPb }\end{array}$ & Former & FRM-1 & $\begin{array}{l}\text { Mengetahui } \\
\text { tujuan } \\
\text { organisasi } \\
\text { melembagakan } \\
\text { instansi } \\
\text { penyusun GFS }\end{array}$ \\
\hline $\begin{array}{l}\text { Kepala } \\
\text { Subdirektorat } \\
\text { Statistik dan } \\
\text { Analisis Laporan } \\
\text { Keuangan, DJPb }\end{array}$ & $\begin{array}{l}\text { Former } \\
\text { dan } \\
\text { Compiler }\end{array}$ & CMP-1 & $\begin{array}{l}\text { Mengetahui } \\
\text { tujuan } \\
\text { organisasi } \\
\text { mengimpleme } \\
\text { ntasikan GFS } \\
\text { dan proses } \\
\text { pelaksanaanny } \\
\text { a }\end{array}$ \\
\hline $\begin{array}{l}\text { Kepala Seksi } \\
\text { Analisa, Statistik } \\
\text { dan Penyusunan } \\
\text { Laporan } \\
\text { Keuangan, DJPb }\end{array}$ & Compiler & CMP-2 & $\begin{array}{l}\text { Mengetahui } \\
\text { proses } \\
\text { implementasi } \\
\text { GFS tingkat } \\
\text { wilayah }\end{array}$ \\
\hline $\begin{array}{l}\text { Kepala Pusat } \\
\text { Kebijakan } \\
\text { Ekonomi Makro, } \\
\text { BKF }\end{array}$ & User & USR-1 & $\begin{array}{l}\text { Mengetahui } \\
\text { fungsi GFS } \\
\text { sebagai } \\
\text { analisis dan } \\
\text { evaluasi } \\
\text { kebijakan } \\
\text { fiskal }\end{array}$ \\
\hline
\end{tabular}

Sumber : Diolah dari berbagai sumber

Wawancara dilakukan dalam suasana formal berlokasi di kantor masing-masing informan. Wawancara dilakukan secara langsung bertatap muka dan menggunakan alat perekaman selama sesi berlangsung. Wawancara menggunakan panduan wawancara berisi tujuan dan poin-poin pertanyaan dalam wawancara seperti pada Lampiran III yang telah disampaikan sebelumnya kepada informan melalui media elektronik (e-mail) khusus untuk USR-1. Informan pada Tabel III.1 merupakan pihak yang memahami dan terlibat langsung dalam implementasi GFS di Indonesia. Melalui wawancara semi terstruktur yang dilakukan peneliti, informasi yang berkembang dari jawaban informan menjadi pertanyaan baru yang peneliti ajukan untuk menekankan hal-hal yang potensial menjawab penelitian ini.

\subsection{Teknik Analisis Data}

Dalam penelitian ini penulis menggunakan teknik analisis data model Miles dan Hubberman. Analisis data dalam penelitian dilakukan pada saat pengumpulan data berlangsung, dan setelah selesai pengumpulan data. Pada saat wawancara, peneliti sudah melakukan analisis terhadap jawaban responden baik dari gerak tubuh, mimik wajah, maupun nada suara. Bila jawaban responden setelah dianalisis belum memuaskan maka peneliti melanjutkan pertanyaan lagi sampai diperoleh data yang kredibel. Miles and Hubberman (1984) dalam Sugiyono (2014) mengemukakan bahwa "aktivitas dalam data kualitatif dilakukan secara interaktif dan berlangsung secara terus-menerus sampai tuntas, sehingga datanya sudah jenuh."

Analisis data pada penelitian ini juga menggunakan model analisis kebijakan interpretatif. Seperti disampaikan Issac (2011) dalam Creswell (2009), bahwa "interpretasi berfokus pada penelitian yang mengungkapkan pemaknaan oleh praktisi, yang dapat digunakan untuk menganalisis permasalahan yang menjadi fokus penelitian." Tujuannya, untuk memahami permasalahan manusia dengan mengartikan yang diinterpretasikan oleh para praktisi. Praktisi dalam penelitian ini adalah pihak pengelola organisasi dan perumus kebijakan. Cara ini juga dapat menginterpretasikan suatu fenomena dari kejadian yang tersembunyi di belakang fenomena tersebut (Guba dan Lincoln, 1994). Aktivitas dalam analisis data terdiri dari tiga, yaitu data reduction, data display, dan conclusion drawing/verification seperti pada Gambar III.3.

Gambar III.3 Komponen Analisis Data

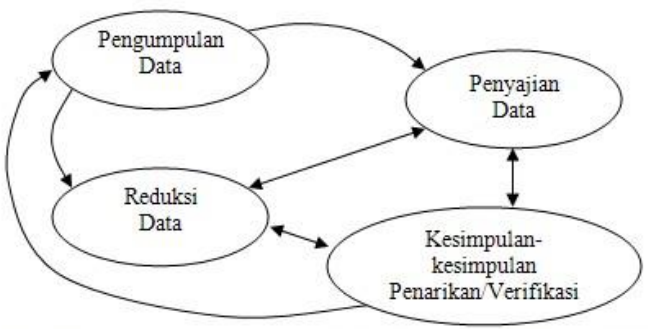

Sumber: Sugiyono. 2014.

\section{HASIL PENELITIAN}

Dalam proses pengumpulan data, penelitian ini mengumpulkan dokumen-dokumen dan hasil wawancara yang digunakan untuk mengidentifikasi adanya tekanan institusional yang mengakibatkan terjadinya isomorphism. Identifikasi tekanan institusional dalam dokumen yang terkait implementasi GFS maupun wawancara semi terstruktur yang dapat memberikan informasi secara eksplisit maupun implisit dibahas pada subsub-bab lebih lanjut. 
Studi dokumentasi dengan mengumpulkan data berupa peraturan yang meliputi undangundang, peraturan pemerintah, peraturan menteri keuangan, dan peraturan direktur jenderal. Selain peraturan juga dikumpulkan dokumen berupa pemberitaan resmi, dan publikasi umum. Dalam analisis dokumen penulis mengidentifkasi keterkaitan antara organisasi dengan tekanan yang melingkupinya dalam implementasi GFS di Indonesia. Dalam Tabel IV.1 diuraikan peraturan perundang-undangan yang mempunyai hierarki dari yang paling tinggi.

\section{Tabel IV.1 Undang-Undang dan Peraturan} Pemerintah

\begin{tabular}{|l|l|}
\multicolumn{1}{|c|}{ Nama Dokumen } & \multicolumn{1}{c}{ Keterkaitan dengan Implementasi } \\
GFS
\end{tabular}

Sumber: Diolah dari berbagai sumber

Undang-undang dan peraturan pemerintah yang menjadi pedoman dalam pelaksanaan implementasi GFS di Indonesia diterbitkan peraturan turunannya pada level Kementerian Keuangan sebagai organisasi yang menjalankan fungsi pelaporan keuangan pemerintah. Tabel IV. 2 menunjukkan uraian keterkaitan antara implementasi GFS dengan peraturan pada level Kementerian Keuangan.
Tabel IV.2 Peraturan Menteri Keuangan dan Peraturan Direktur Jenderal Perbendaharaan

Nama
Dokumen

Sumber: Diolah dari berbagai sumber

Peraturan-peraturan yang menjadi landasan organisasi dalam implementasi GFS di Indonesia secara timeline terdapat lag antara peraturan yang mempunyai hierarki lebih tinggi dengan hierarki di bawahnya. Pertama, terbitnya Peraturan Pemerintah No 71 tahun 2010 terkait dengan basis akuntansi akrual mempunyai jarak 6 tahun dengan peraturan yang melandasinya, yaitu UndangUndang No 1 Tahun 2004. Selama enam tahun penyusunan laporan keuangan pemerintah yang seharusnya memuat informasi statistik keuangan seperti amanat UU No 1 Tahun 2004 mengalami kendala. Kendala tersebut adalah penggunaan basis akuntansi Cash Towards Accrual yang tidak selaras dengan basis akuntansi yang seharusnya digunakan dalam penyusunan informasi statistik keuangan yaitu basis akuntansi akrual. Selain itu, tidak ada standar yang mengatur Laporan Statistik Keuangan Pemerintah. Kedua, Perdirjen Perbendaharaan Nomor 41/PB/2013 terkait dengan petunjuk teknis penyusunan laporan statistik keuangan pemerintah tingkat wilayah terbit terlebih dahulu daripada Peraturan Menteri Keuangan Nomor 275/PMK.05/2014. Penyusunan Laporan Statistik Keuangan Pemerintah pada dasarnya berpedoman pada Manual Statistik Keuangan Pemerintah Indonesia, tetapi peraturan 
tersebut belum terbit ketika Laporan Statistik Keuangan Pemerintah mulai disusun. Selain adanya overlap juga adanya preceding hierarki peraturan, yaitu peraturan direktur jenderal yang mendahului peraturan menteri keuangan di mana dalam hierarki peraturan adalah lebih rendah. Penerbitan Perdirjen Perbendaharaan Nomor 41/PB/2013 merupakan salah satu respon organisasi dalam menindaklanjuti Peraturan Menteri Keuangan Nomor 169/PMK.01/2012 tentang Organisasi dan Tata Kerja Instansi Vertikal Direktorat Jenderal Perbendaharaan. Walaupun pada substansinya, penyusunan Laporan Statistik Keuangan Tingkat Wilayah hanya merupakan bagian dari Perdirjen Perbendaharaan Nomor 41/PB/2013 yang juga mengatur tentang laporan konsolidasian.

Sebagai bagian dari proses implementasi GFS di Indonesia, pemerintah telah melakukan kegiatan-kegiatan yang menuju implementasi lebih komprehensif. Dokumentasi kegiatan yang berupa pemberitaan pada website resmi organisasi baik dari Kementerian Keuangan maupun DJPb terdapat pada Lampiran I dan Lampiran II penelitian ini. Studi literatur dan telaah dokumen yang digunakan dalam penelitian ini didukung dengan wawancara semi terstruktur kepada informan-informan terkait. Informan memberikan informasi, pendapat, tanggapan, dan pengalamannya masing-masing sesuai dengan latar belakang tingkat jabatan dan fungsi kedudukan dalam organisasi.

Respon organisasi Kementerian Keuangan c.q. Direktorat Jenderal Perbendaharaan sebagai akibat dari adanya tekanan-tekanan institusional yang melingkupinya. Tekanan institusional tersebut terbagi menjadi tiga, yaitu coersive pressure, mimetic pressure, dan normative pressure yang diuraikan pada subbab berikut.

\subsection{Coersive Pressure}

Implementasi GFS di Indonesia terkait dengan berbagai pihak baik dari dalam maupun luar institusi organisasi. Menurut identifikasi, coersive pressure yang terjadi berasal dari organisasi lain yang lebih tinggi baik dari dalam maupun dari luar negeri. Tekanan institusional berupa coersive pressure dihadapi organisasi sejak awal mula implementasi hingga dalam perjalanan saat ini. Berdasarkan hasil studi dokumentasi dan didukung dengan wawancara, gejala coersive pressure dalam implementasi GFS teridentifikasi beberapa, yaitu sebagai berikut:

\subsubsection{Amanat Undang Undang Nomor 1 Tahun 2004 tentang Perbendaharaan Negara.}

Pada penjelasan umum Undang Undang Nomor 1 Tahun 2004 dijelaskan bahwa laporan keuangan pemerintah dapat menghasilkan statistik keuangan yang mengacu kepada manual Government Finance Statistics sehingga dapat memenuhi kebutuhan analisis kebijakan dan kondisi fiskal, pengelolaan dan analisis perbandingan antar negara (cross country studies), kegiatan pemerintahan, dan penyajian statistik keuangan pemerintah. Jelas terlihat bahwa amanat undang-undang tersebut memberikan tekanan kepada organisasi $\mathrm{DJPb}$ sebagai organisasi yang mempunyai fungsi pelaporan keuangan pemerintah untuk menyajikan data statistik keuangan.

\subsubsection{Pelaksanaan rekomendasi IMF atas basis standar pelaporan keuangan negara menggunakan standar yang berlaku internasional.}

Indonesia termasuk dalam anggota IMF. IMF bertugas memantau perekonomian dan kebijakan keuangan negara anggotanya dan dunia. IMF sebagai organisasi dunia melakukan assessment terhadap data keuangan Indonesia sebagai salah satu negara anggota pada tahun 2005 yang terpublikasi dalam "Indonesia: Report on the Observance of Standards and Codes-Data Module, Response by the Authorities, and Detailed Assessments Using the Data Quality Assessment Framework". Dalam publikasi tersebut ditemukan bahwa data keuangan Indonesia tidak memenuhi standar internasional yang dapat menyajikan data keuangan regional dengan basis standar. Sehingga data keuangan Indonesia tidak dapat digunakan secara optimal untuk kepentingan analisis ekonomi dunia, padahal praktik pelaporan statistikal telah diamanatkan Undang Undang Nomor 1 Tahun 2004. Pelaporan statistikal itu merupakan pelaporan berbasis internasional.

Rekomendasi IMF terhadap assesment data keuangan Indonesia adalah sebagai berikut (diterjemahkan oleh penulis):

a. Menerapkan standar akuntansi pemerintah baru;

b. Memperkuat sistem pengelolaan saat ini untuk melacak secara efektif saldo kas pemerintah;

c. Beralih secara bertahap ke sistem akuntansi akrual;

d. Menyiapkan daftar semua sektor publik pemerintah pusat, yang diklasifikasikan sesuai sektor institusional;

e. Mengubah peraturan akuntansi untuk memastikan bahwa unit pemerintah umum melaporkan semua transaksi dan saldo di mana dapat dikontrol;

f. Mengkompilasi dan mempublikasikan GFS untuk sektor pemerintah umum dan subsektornya dalam jangka waktu enam bulan setelah akhir periode referensi;

g. Mengatur perjanjian untuk mendapatkan data awal secara tepat waktu dari pemerintah daerah.

h. Membuat prosedur kompilasi untuk statistik keuangan pemerintah pusat dan daerah;

i. Mengembangkan GFSM untuk operating statement, statement of source and uses cash, dan (sebagian) neraca, sampai dengan data yang 
paling terakhir dan mempublikasikan laporan pada situs Kementerian Keuangan.

Pada rekomendasi tersebut jelas disebutkan bahwa implementasi GFS merupakan langkah yang direkomendasikan untuk memperbaiki pelaporan keuangan dengan terlebih dahulu mengubah standar akuntansi pelaporan keuangan menjadi basis akrual. Dengan basis akrual, data keuangan dapat diperbandingkan secara cross country studies dan disajikan menggunakan format yang standar internasional yaitu format GFS. Perubahan basis akuntansi menuju akrual dilakukan secara bertahap. Pada masa transisi tersebut digunakan basis akuntansi Cash Towards Accrual. Selain itu, publikasi GFS pun disebutkan pada rekomendasi dalam jangka waktu enam bulan setelah periode referensi (anggaran) yang menjadi sebuah tekanan terhadap organisasi untuk bereaksi meresponnya.

\subsubsection{Pelaksanaan rekomendasi G20 dalam} implementasi DGI (Data Gap Initiative) agar data statistik keuangan menggunakan Sectoral Account.

Indonesia termasuk negara yang ikut dalam forum negara G20. Rekomendasi yang diberikan oleh G20 tersebut muncul setelah adanya evaluasi selama lima tahun dari tahun 2009 sampai dengan 2014 dalam publikasi seminar "The Joint FSB/IMF Global Conference" di Basel, Switzerland pada tanggal 25 s.d. 26 Juni 2014, pada website IMF. Rekomendasi tersebut dalam rangka menyelesaikan masalah kesenjangan ketersediaan data untuk keperluan analisis kebijakan fiskal dan makro ekonomi. Rekomendasi G20 melibatkan empat institusi pemerintah yang saling berhubungan dalam menyelesaikan permasalahan Sectoral Account seperti pada Gambar IV.3.

Gambar IV.3 Pengaturan Lembaga Pemerintah dalam Penyelesaian Sectoral Account

\begin{tabular}{|c|c|c|c|}
\hline BPS & BI & MOF & OJK \\
\hline $\begin{array}{l}\text { - Households } \\
\text { - NPISHs } \\
\text { - Non Financial } \\
\text { Corporations }\end{array}$ & $\begin{array}{l}\text { - Central Bank } \\
\text { - Bank } \\
\text { - ROW }\end{array}$ & $\begin{array}{l}\text { - Central } \\
\text { Government } \\
\text { - Local } \\
\text { Government }\end{array}$ & $\begin{aligned} & \text { - Non Bank } \text { Financial } \\
& \text { Institutions } \\
& \text { - Bank } \\
& \text { - Capital } \\
& \text { market }\end{aligned}$ \\
\hline $\begin{array}{l}2008 \text { SNA } \\
\text { implementation } \\
\text { in } 2015\end{array}$ & $\begin{array}{c}\text { Providing FSA in annual } \\
\text { basis for Central Bank, } \\
\text { Bank, ROW + quarterly } \\
\text { Financial Accounts in } \\
2014\end{array}$ & $\begin{array}{l}\text { GFS manual } \\
\text { implementation } \\
\text { in } 2014\end{array}$ & \\
\hline
\end{tabular}

Sumber: www.imf.org

Pada Gambar IV.3 terlihat bahwa Kementerian Keuangan beserta semua unit dibawahnya berperan sebagai institusi yang mengimplementasikan GFSM pada tahun 2014 dalam rangka menyempurnakan data keuangan yang terkait dengan Sectoral Account karena belum memadai. Rekomendasi G20 terhadap Indonesia yang lebih spesifik adalah untuk mengimplementasikan GFSM 2014 baik tingkat pusat maupun wilayah.

\subsubsection{Kebutuhan lembaga rating (Moodys dan} S\&P) dalam rangka ketersediaan data yang digunakan untuk menilai kapasitas fiskal yang berkaitan dengan pemberian pinjaman dan pengambilan keputusan investor.

Data GFS digunakan oleh lembaga rating dalam melakukan analisis kualitas dan kesinambungan kemampuan keuangan pemerintah dalam rangka menilai dan memberikan rating surat berharga suatu negara. Ketika lembaga rating tersebut ke Indonesia, maka data yang berlaku internasional adalah data yang mampu menyediakan informasi yang dapat dibaca oleh orang asing dengan standar yang berlaku internasional. Seperti yang dijelaskan oleh CMP-1 dalam interviu bahwa lembaga rating yang datang ke Indonesia untuk melakukan assesment memerlukan data yang komprehensif. GFS dapat menyediakan data yang komprehensif dari pemerintah pusat sampai dengan pemerintah daerah, bahkan ke depan terdapat data BUMN dan BUMD. Hal tersebut tentunya akan lebih mudah bagi lembaga rating untuk direct use daripada mengkompilasi satu per satu. Data GFS akan memberikan gambaran secara lebih komprehensif tentang kinerja dan kondisi keuangan pemerintah secara internasional.

Kebutuhan data berstandar internasional tersebut mendukung assesment lembaga rating. Tentu saja hal itu membuat tekanan kepada organisasi untuk mengimplementasikan GFS sesuai standar internasional. Organisasi berperan dalam menyediakan data dengan salah satu urgensi kepentingan pihak di luar organisasi.

\subsubsection{Pelaksanaan rekomendasi Badan Anggaran DPR RI dalam upaya perbaikan pengelolaan keuangan negara.}

Dalam publikasi berita resmi pada website Kementerian Keuangan pada acara Rapat Kerja Menteri Keuangan dengan Badan Anggaran DPR RI pada tanggal 31 Agustus 2015 menyebutkan 8 rekomendasi dan kesepakatan terkait dengan hasil pembahasan/pembicaraan tingkat I RUU tentang Pertanggungjawaban atas Pelaksanaan APBN Tahun Anggaran 2014 (RUU P2 APBN TA 2014). Rekomendasi ke-6 menyebutkan bahwa pemerintah agar menerapkan dan menyusun statistik keuangan pemerintah (Government Finance Statistics) yang mengacu pada Manual Statistik Keuangan Pemerintah 
Indonesia, konsolidasi fiskal, dan statistik (Kemenkeu, 2015). Rekomendasi ini menjadi acuan Pemerintah Indonesia dalam hal ini Kementerian Keuangan c.q. Direktorat Jenderal Perbendaharaan untuk lebih komitmen terhadap perbaikan implementasi GFS.

Gejala-gejala adanya coercive pressure dalam implementasi GFS di Indonesia yang telah diuraikan di atas mendapat respon dari organisasi. Respon tersebut dilakukan yang pertama, diterbitkannya Peraturan Pemerintah No. 24 Tahun 2005 tentang Standar Akuntansi Pemerintah yang diubah menjadi Peraturan Pemerintah No. 71 Tahun 2010. Peraturan turunannya adalah PMK No. 238/PMK.05/2011 tentang Pedoman Umum Sistem Akuntansi Pemerintah, PMK No. 169/PMK.05/2012 tentang Organisasi dan Tata Kerja Instansi Vertikal Direktorat Jenderal Perbendaharaan, dan Perdirjen Perbendaharaan No. 41/PB/2013 tentang Petunjuk Teknis Penyusunan Laporan Keuangan Pemerintah Konsolidasian Tingkat Wilayah dan Laporan Statistik Keuangan Pemerintah Tingkat Wilayah pada Kantor Wilayah Direktorat Jenderal Perbendaharaan.

Respon penerbitan peraturan merupakan respon organisasi atas amanat Undang Undang Nomor 1 Tahun 2004 dan respon atas coersive pressure dari organisasi yang lebih tinggi dalam hal ini IMF dan forum negara G20. Respon kelembagaan Kantor Wilayah DJPb menjadi instansi vertikal yang menyusun GFS tingkat wilayah merupakan respon yang tertuang dalam rencana strategis Direktorat Jenderal Perbendaharaan melalui penajaman fungsi kantor wilayah. Selain itu juga adanya penerbitan Peraturan Menteri Keuangan Nomor 169/PMK.01/2012 tentang Organisasi dan Tata Kerja Instansi Vertikal Direktorat Jenderal Perbendaharaan. Pernyataan itu diperkuat dengan informasi dari informan FRM-1 bahwa terdapat isu mapping account yang jika dilakukan hanya terpusat pada Direktorat Akuntansi dan Pelaporan Keuangan akan memerlukan waktu dan tenaga yang banyak. Hal tersebut mendorong ide jika Kantor Wilayah DJPb yang secara geografis lebih dekat dengan pemerintah daerah akan mudah memperoleh data langsung dari sumbernya. Maka dari itu, Kantor Wilayah DJPb diberikan tugas dan fungsi menyusun Laporan GFS Tingkat Wilayah.

Kedua, diterbitkannya Peraturan Menteri Keuangan Nomor 275/PMK.05/2014 tentang Manual Statistik Keuangan Pemerintah Indonesia (Mansikapi). Mansikapi ini berdasar pada GFSM 2001 yang diterbitkan oleh IMF, sementara pada saat diterbitkan peraturan tersebut, GFSM telah direvisi menjadi GFSM 2014. Berdasarkan publikasi seminar "The Joint FSB/IMF Global Conference", Indonesia sedang dalam proses implementasi menggunakan GFSM 2014 bahwa
"Indonesia reports annual general government data and will compile quarterly general government data (flow data) presented under GFSM 2014 by 2016. Indonesia is in the process of reporting quarterly general government data and therefore it will meet the proposed implementation target by 2016".

Sebagai langkah lebih lanjut dalam menerapkan PMK 275/PMK.05/2014, Laporan GFS yang dihasilkan disampaikan kepada stakeholder dan user GFS. Salah satunya kepada IMF dengan beberapa kondisi data yang relevan disampaikan seperti yang diinformasikan oleh informan CMP-1 bahwa Indonesia sebagai negara anggota IMF mempunyai kewajiban untuk menyampaikan laporan GFS . Akan tetapi, IMF tidak bisa memaksakan bentuk dan detail data yang akan disampaikan. Pemerintah Indonesia menyaring data apa yang layak untuk disampaikan ke IMF dan data yang digunakan hanya untuk kepentingan internal pemerintah. Seperti data yang menyangkut keamanan negara terkait alutsista dan lain-lain tidak disampaikan kepada IMF.

Ketiga, diluncurkannya website resmi www.gfs.djpb.kemenkeu.go.id pada akhir Desember 2015 berdasarkan pemberitaan resmi pada website $\mathrm{DJPb}$. Peluncuran website GFS ini merupakan respon dari rekomendasi G20 untuk mempublikasikan data GFS pada website resmi Kementerian Keuangan. Walaupun laman GFS ini merupakan bagian dari laman utama DJPb dengan menjadikan menu di laman utama, sudah terlihat bahwa website GFS menjadi bagian dari website Kementerian Keuangan.

Respon-respon yang dilakukan organisasi dalam menghadapi tekanan institusional berupa coersive pressure ini masih terdapat hambatan berupa peraturan teknis yang masih belum terupdate dengan basis akuntansi akrual seperti keterangan informan CMP 1 bahwa akan dilakukan penyempurnaan PER-41/PB/2013 terkait petunjuk teknis penyusunan LKPK-TW dan LSKPTW pada Kanwil DJPb. Hal ini karena PER41/PB/2013 merupakan petunjuk teknis berbasis CTA. Selain itu akan dilakukan revisi PMK 238 karena PMK tersebut disusun pada waktu BAS Pemerintah Pusat dan BAS Pemerintah Daerah belum selesai.

\subsection{Mimetic Pressure}

Tekanan institusional mimetic pressure dalam implementasi GFS di Indonesia terlihat pada gejala organisasi dalam melakukan sebuah kebijakan atau sebuah tindakan untuk meniru praktik sejenis pada organisasi lain. Tindakan yang dilakukan organisasi ini mengindikasikan adanya kemiripan dengan tidak mempertimbangkan apakah organisasi membutuhkan atau tidak atas tindakan tersebut

Pada tahun 2011 saat implementasi GFS awal dilakukan, pelaporan keuangan Indonesia mendapatkan apresiasi dari Kementerian Australia 
melalui Government Partnership Fund (GPF) Finance Team Leader. Bahwa pelaporan tersebut dapat menjadi inspirasi developing country dalam kapasitas pelaporan keuangan. Hal tersebut tentunya tidak terlepas dari usaha organisasi melakukan best practice pada pelaporan keuangan seperti negara Australia yang sudah lebih maju. Pernyataan tersebut disampaikan melalui pemberitaan resmi pada website Kementerian Keuangan.

Australia telah mengimplementasikan GFS sebelum tahun 1986. Sedangkan, IMF membuat GFSM pertama kali pada tahun 1986. Hal tersebut menjadi salah satu pertimbangan organisasi mengimplementasikan GFS dengan berkaca pada Australia. Pernyataan ini diperkuat dengan informasi yang disampaikan oleh informan CMP-1 bahwa Australia adalah salah satu negara terbaik penyusun laporan GFS sehingga mampu melakukan sharing tentang bagaimana pengalaman mereka menyusun GFS. Australia sudah puluhan tahun menyusun GFS. Bahkan sudah menyusun GFS sebelum manual IMF terbit pada tahun 1986. Hal tersebut menginspirasi untuk belajar dari pengalaman, pengetahuan, best practice yang bisa disharing oleh pihak luar.

$\mathrm{DJPb}$ melakukan kerjasama internasional untuk menyempurnakan implementasi GFS baik dengan IMF maupun GPF. Kerjasama ini menunjukan adanya pengaruh timbal balik mengenai ketersediaan data yang saling membutuhkan antara Pemerintah Indonesia dengan pihak luar tersebut. Kerjasama dengan Pemerintah Australia menunjukkan gejala adanya tekanan institusional mimetic pressure. Praktik implementasi GFS di Australia menjadi acuan implementasi GFS di Indonesia. Dukungan yang diberikan Pemerintah Australia melalui GPF ini berupa penyediaan dana pengembangan website GFS, memberikan Shortcourse Accrual Accounting, penyediaan dana pembuatan buku Accrual Accounting Journey dan penerjemahan LKPP.

Hadirnya GPF dalam implementasi GFS di Indonesia merupakan kelanjutan dari pemberian hibah pada tsunami Aceh tahun 2004. Hibah bilateral tersebut merupakan hibah terbesar Australia sepanjang sejarah negaranya. Dalam rangka menjaga momentum tersebut maka dibangun partnership yang sustainable melalui GPF pada tahun 2007. Kerjasama internasional ini berakhir pada bulan Juni tahun 2017 tetapi ada kemungkinan dilakukan perpanjangan menurut informasi hasil observasi lapangan penulis. Dalam mendukung kegiatan operasionalnya, GPF mendirikan kantor sekretariat di lingkungan Kementerian Keuangan dengan menempatkan beberapa pemangku kepentingan dari Kementerian Keuangan untuk mendampingi. Fokus GPF ini pada awalnya tentang pelaporan keuangan pada Direktorat Jenderal Perbendaharaan. Tetapi pada tahun-tahun selanjutnya meluas hingga ke Direktorat Jenderal Anggaran dalam pengembangan Performance Based Budgeting dan Medium Term Expenditure Framework. Selain itu juga meluas kepada Direktorat Jenderal Kekayaan Negara dalam isu mengenai asset management dan Sekretariat Jenderal Kementerian Keuangan dalam transformasi kelembagaannya.

Gejala mimetic pressure juga terlihat dalam salah satu tujuan organisasi menyampaikan laporan GFS kepada IMF, yaitu keinginan untuk menampilkan keterbukaan informasi seperti yang dilakukan oleh negara lain. Organisasi juga ingin melakukan keterbukaan informasi agar dapat tampil sama dengan negara lain di dunia internasional. Seperti yang disampaikan oleh informan FRM-1 bahwa Pemerintah Indonesia ingin menjadi lebih transparan di dunia internasional. Sebagai contoh jika Amerika bisa memberikan informasi banyak kepada dunia tentang negaranya, maka Indonesia juga bisa melakukan hal yang sama melalui data yang dipublish oleh IMF, tentang GDP, budget, maupun publik sektornya.

Respon organisasi dalam menghadapi tekanan institusional mimetic pressure ini adalah dengan melakukan capacity building, training, short course, lokakarya dan diklat. Respon yang dilakukan ini bertujuan untuk meningkatkan pengetahuan dan konsepsi pemahaman metodologi GFS. Seperti yang ada pada pemberitaan resmi website Kementerian Keuangan bahwa telah dilakukan kegiatan beberapa di antaranya seperti pada Tabel IV.3.

Tabel IV.3 Respon Organisasi Terhadap Mimetic Pressure

\begin{tabular}{|c|c|c|}
\hline $\begin{array}{l}\text { Nama } \\
\text { Kegiatan }\end{array}$ & $\begin{array}{l}\text { Tempat dan } \\
\text { Tanggal } \\
\text { Pelaksanaan }\end{array}$ & Narasumber \\
\hline $\begin{array}{l}\text { Lokakarya } \\
\text { GFS }\end{array}$ & $\begin{array}{l}23 \text { s.d. } 25 \\
\text { September } \\
2013\end{array}$ & $\begin{array}{l}\text { GFS Expert dari IMF, } \\
\text { GPF, Perwakilan } \\
\text { Negara ASEAN yang } \\
\text { telah menerapkan GFS, } \\
\text { Direktur Jenderal } \\
\text { Perbendaharaan, } \\
\text { Direktur Akuntansi dan } \\
\text { Pelaporan Keuangan, } \\
\text { dan para pejabat di } \\
\text { lingkungan Ditjen } \\
\text { Perbendaharaan. }\end{array}$ \\
\hline $\begin{array}{l}\text { Lokakarya } \\
\text { SIRI }\end{array}$ & 25 Juli 2016 & $\begin{array}{l}\text { IMF, } \\
\text { Perbendaharaan, Ditjen } \\
\text { Perimbangan } \\
\text { Keuangan, } \\
\text { Indonesia, dan } \\
\text { Pusat Statistik. }\end{array}$ \\
\hline Diklat GFS & $\begin{array}{l}26-29 \\
2016\end{array}$ & $\begin{array}{l}\text { IMF, Ditjen } \\
\text { Perbendaharaan, dan } \\
\text { DJPPR }\end{array}$ \\
\hline
\end{tabular}

Sumber: Diolah dari www.kemenkeu.go.id 
Respons organisasi dalam mengimplementasikan GFS merupakan reaksi yang ditimbulkan dari adanya tekanan institusional mimetic pressure diperkuat dengan informasi dari informan CMP-1 bahwa akan dilaksanakan peningkatan kapasitas berupa workshop dan training setiap tahun. Training yang dilaksanakan di Gadog, Bogor menggandeng BPPK dengan menghadirkan narasumber langsung dari IMF. Hal tersebut dilakukan setiap 2 sampai 3 tahun sekali untuk meningkatkan pemahaman atas konsepsi dan metodologi GFS. Selain itu juga ada TOT berkala menggandeng BPPK yang bertujuan supaya kanwil bisa memahami juknis atau teknik penyusunan laporan GFS. Short course kerjasama dengan Universitas Brawijaya untuk memperkaya dari sisi konsepsi akuntansi sebagai data dukung GFS dan konsepsi GFS dari sisi teoritis juga pernah dilakukan.

Selain itu, respon organisasi adalah dengan melakukan migrasi Standar Akuntansi Pemerintah berbasis Cash Towards Accrual menjadi basis Accrual. Migrasi basis akuntansi sebagai langkah reformasi pengelolaan keuangan negara yang dibuktikan dengan adanya perubahan peraturan Peraturan Pemerintah Nomor 24 tahun 2005 menjadi Peraturan Pemerintah Nomor 71 Tahun 2010.

\subsection{Normative Pressure}

Jenis tekanan institusional yang ketiga adalah normative pressure. Gejala yang terlihat dalam implementasi GFS di Indonesia ada beberapa diantaranya adalah sebagai berikut:

\subsubsection{Penyelarasan perangkat organisasi oleh Kementerian Keuangan sebagai institusi pengelola fiskal demi terwujudnya good governance.}

$\mathrm{DJPb}$ terbentuk dari kelanjutan lahirnya paket Undang-Undang Keuangan Negara yang terdiri atas Undang-Undang Nomor 17 tahun 2003 tentang Keuangan Negara, Undang-Undang Nomor 1 tahun 2004 tentang Perbendaharaan Negara, dan Undang-Undang Nomor 15 tahun 2004 tentang Pemeriksaan Pengelolaan dan Tanggung Jawab Keuangan Negara. Cikal bakal DJPb pada saat itu tercermin pada Direktorat Jenderal Anggaran dengan karakteristik fungsi ordonatur dan otorisasi serta kewenangan yang sangat luas (Kemenkeu, 2015). Kewenangan debt management, asset management, budget planning and execution yang menjadi satu, memunculkan paradigma baru bahwa pembagian wewenang dan mekanisme check and balance adalah penting dalam pengelolaan keuangan negara. Pengelolaan keuangan negara yang mencerminkan good governance meliputi pengelolaan yang transparan, efektif, efisien dan dapat dipertanggungjawabkan. Dari hal tersebutlah yang memunculkan reformasi organisasi dengan lahirnya organisasi DJPb sebagai unit Eselon I di Kementerian Keuangan.

Reformasi hukum dan reformasi organisasi di dalamnya memuat pertanggungjawaban pengelolaan keuangan negara harus menyediakan data statistik keuangan. Seperti yang disampaikan oleh CPM-1 dalam interviu bahwa pengaturan mengenai GFS ada di Undang Undang No. 1 tahun 2004 tentang Perbendaharaaan Negara dan di dalam penjelasan itu disebutkan bahwa laporan keuangan perlu disusun salah satunya dapat menyajikan statistik keuangan pemerintah yang mengacu pada manual statistik keuangan pemerintah. Dari tahun 2004 ada beberapa UU P2 APBN yang juga kembali mengatur mengenai GFS itu antara lain UU P2 APBN No. 23 tahun 2009 kemudian diatur kembali di UU P2 APBN No. 24 tahun 2015.

UU P2 APBN merupakan undang-undang tentang Pelaksanaan dan Pertanggungjawaban Anggaran Pendapatan dan Belanja Negara. Dalam UU P2 APBN pada dua tahun anggaran tersebut diatur mengenai implementasi GFS sebagai bagian dari pertanggungjawaban yang mencerminkan prinsip good governance.

\subsubsection{Mewujudkan visi DJPb untuk menjadi pengelola perbendaharaan negara yang unggul di tingkat dunia.}

Adaptasi dan publikasi GFS yang dilakukan pemerintah merupakan langkah yang ditempuh untuk terlibat dalam dunia internasional seperti yang disampaikan oleh FRM-1 dalam interviu bahwa Pemerintah Indonesia mengadopsi dan mempublikasi GFS karena ingin masuk ke kancah internasional meskipun pada tahun itu belum punya visi misi baru menjadi pengelola kelas dunia, sebenarnya dengan mengadopsi GFS membuktikan kita mencoba melangkah ke kelas dunia.

\subsubsection{Penajaman fungsi Kantor Wilayah DJPb sebagai unit representasi Kementerian Keuangan di daerah dalam bidang fiskal.}

Kantor Wilayah DJPb terdiri dari 33 satuan kerja tersebar di seluruh Indonesia mempunyai fungsi sebagai unit instansi yang merupakan representasi Kementerian Keuangan di daerah. Bidang yang menjadi fungsi Kantor Wilayah DJPb adalah fungsi bidang fiskal yang terdiri dari fungsi pembinaan keuangan pusat dan daerah, fungsi analisis belanja pemerintah dan fungsi konsolidasi APBN dan APBD dalam Laporan GFS. Berdasarkan Peraturan Menteri Keuangan Nomor 169/PMK.05/2012 tentang Organisasi dan Tata Kerja Instansi Vertikal Direktorat Jenderal Perbendaharaan tersebut diantaranya mengatur tugas dan fungsi kantor wilayah dalam penyusunan laporan GFS pada Pasal 20 ayat 3 .

Latar belakang diterbitkannya PMK Nomor 169/PMK.05/2012 ini adalah seperti yang tertuang 
dalam dokumen rencana strategis DJPb 2015-2019 sebagai berikut:

Dalam rangka meningkatkan kinerja kantor vertikal di lingkungan Ditjen Perbendaharaan dan mendukung terwujudnya tata kelola keuangan negara dan kekayaan negara secara profesional, produktif, transformatif sesuai dengan Transformasi Kelembagaan Kementerian Keuangan, serta mendukung sinergi antar unit eselon I Kementerian Keuangan telah dilaksanakan penataan Organisasi dan Tata Kerja Instansi Vertikal Direktorat Jenderal Perbendaharaan melalui PMK Nomor 169/PMK/2012 pada tanggal 6 November 2012.

\subsubsection{Penggunaan informasi akuntansi pemerintah tidak sekedar sebagai laporan pertanggungjawaban.}

Gejala adanya normative pressure dalam implementasi GFS di Indonesia terlihat dalam semangat penyusunan laporan keuangan pemerintah untuk tujuan tidak sekedar laporan pertanggungjawaban. Pernyataan ini didukung dengan informasi dari informan CMP-1 bahwa laporan keuangan perlu lebih dari sekedar pertanggungjawaban, tetapi ada fungsi feed back dan fungsi informasi dalam pengambilan keputusan. Maka dari itu dibentuk Subdirektorat Statistik dan Analisis Laporan Keuangan untuk membuat analisis-analisis data yang sudah ada untuk kebutuhan pimpinan, di mana ada fungsi pelaporan manajerial perbendaharaan. Di sisi lain, informasi tersebut bisa disusun dalam bentuk statistik yang bisa memenuhi kebutuhankebutuhan tentang kebijakan fiskal dan kebutuhan Bank Indonesia, dan Badan Pusat Statistik untuk menghitung kinerja ekonomi nasional.

\subsubsection{Keterbukaan data informasi keuangan negara dalam dunia internasional.}

Keterbukaan informasi kepada dunia luar menjadi salah satu semangat implementasi GFS di Indonesia. Keterbukaan informasi tersebut dapat digunakan oleh negara lain dalam mempertimbangkan kerjasama dengan Indonesia. Pernyataan ini didukung dengan informasi dari informan FRM-1 bahwa dalam hubungan bilateral dan multilateral, negara lain akan lebih memilih kepada negara yang terbuka, semakin jelas dan transparan, negara- negara semakin leluasa berhubungan. Dengan pertukaran data GFS maka negara semakin terbuka.

\subsubsection{Mengingat pentingnya terdapat data yang valid dan komprehensif antar sektor untuk tujuan analisis dan evaluasi kebijakan fiskal.}

Data yang valid dan komprehensif antar sektor menjadi penting untuk keperluan internasional. Selain itu kesesuaian atau sinkronisasi informasi sektor fiskal dan di sektor lain, baik sektor moneter atau sektor riil menjadi langkah yang harus ditempuh oleh organisasi dengan mengimplementasikan GFS. Sinkronisasi informasi mendorong dalam penggunaan informasi akuntansi untuk kebijakan fiskal dan mempengaruhi kontribusi pemerintah dalam sektor perekonomian. Pernyataan tersebut didukung dengan informasi dari informan CMP-1 bahwa dari negara G20 lahir kesepakatan bahwa masing-masing negara akan mendorong, meminimalisasi data gap di dalam negara masingmasing sehingga ini akan mempermudah para pengambil kebijakan mengambil kebijakan. IMF menggunakan data itu untuk melaksanakan fungsinya sebagai lembaga yang memonitor perekonomian dan moneter dunia.

4.3.7. Whole government reporting sebagai bagian dari rencana strategis organisasi.

Pemerintah Indonesia saat ini belum mempunyai output yang mencerminkan kondisi keuangan pemerintah secara utuh. Utuh dalam arti mencangkup pemerintah pusat dan pemerintah daerah menjadi kesatuan yang terintegrasi. Rencana Strategis Direktorat Jenderal Perbendaharaan tahun 2015 - 2019 mencantumkan langkah untuk melakukan konsolidasi APBN dan APBD. Pernyataan dari informan CMP-1 membuktikan bahwa terdapat gejala normative pressure ini pada tujuan diimplementasikan GFS di Indonesia. Implementasi GFS salah satunya untuk pengambilan keputusan dan kebijakan. Salah satunya dengan laporan konsolidasian pemerintah dan laporan GFS. Terkait dengan hal tersebut Pemerintah Indonesia sudah menyusun laporan konsolidasi LKPP dengan 542 pemerintah daerah tahun 2015. Laporan tesebut merupakan whole government reporting dan bertujuan untuk laporan pertanggungjawaban ke DPR dan DPRD. Dengan laporan tersebut bisa dilihat kinerja dan kondisi keuangan pemerintah secara keseluruhan dan secara akuntansi.

Gejala-gejala normative pressure dalam implementasi GFS mendapatkan respon oleh organisasi $\mathrm{DJPb}$. Respon organisasi adalah dengan menjadikan implementasi GFS dalam Rencana Strategis Direktorat Jenderal Perbendaharaan Tahun 2015-2019 dalam fungsi akuntansi dan pelaporan keuangan. Respon lainnya yang telah dilakukan organisasi adalah dengan pembentukan Tim Statistik Keuangan Pemerintah yang berasal dari lingkup Kementerian Keuangan, Kementerian Dalam Negeri, Kementerian Badan Usaha Milik Negara, Badan Pusat Statistik dan Bank Indonesia.

Selain itu, organisasi merespon dengan memberdayakan Kantor Wilayah DJPb dengan diterbitkannya PMK 169/PMK.05/2012 yang didukung dengan pernyataan dari informan FRM-1 bahwa bagaimana jika di kanwil dilakukan pemberdayaan. Hal tersebut dimitigasi apakah mereka mempunyai kompetensi terkait akuntansi yang digunakan untuk pondasi. Kompetensi dapat 
dibentuk, yang utama adalah pemberian mandat terlebih dulu.

Pernyataan informan FRM-1 diperkuat dengan pernyataan dari CMP-1 bahwa diskusi melembagakan kanwil dimulai ketika ada wacana untuk merevitalisasi fungsi kanwil sebagai perwakilan Kementerian Keuangan di daerah. Pada waktu itu diidentifikasi fungsi-fungsi Kementerian Keuangan dan kantor pusat apa saja yang bisa dilakukan kanwil sebagai perwakilan Kementerian Keuangan di daerah. Terkait dengan hal itu adalah fungsi pelaporan GFS. Mereka bisa berkontribusi baik untuk penghitungan statistik wilayah sebagai partner Pemda untuk mengambil kebijakan fiskal. Salah satu data GFS akan dituangkan dalam bentuk KFR yang saat penelitian ini disusun sedang disempurnakan konsepnya menjadi konsep yang lebih komprehensif.

Gejala-gejala normative pressure yang muncul direspon oleh organisasi DJPb. Ternyata, pelaksanaan implementasi GFS ini mengalami berbagai kendala. Kendala yang terjadi salah satunya adalah data pada laporan GFS memerlukan peningkatan dalam hal validitas, kredibilitas dan reliabilitas. Penggunaan data dan informasi GFS sebagai analisis dan evaluasi kebijakan fiskal memerlukan extra effort dari organisasi $\mathrm{DJPb}$. Laporan GFS yang ada pada saat ini belum digunakan secara optimal untuk kepentingan internal Kementerian Keuangan. Sesuai dengan informasi dari salah satu pengguna informasi GFS USR-1 bahwa implementasi GFS masih perlu ditingkatkan. USR-1 menjelaskan bahwa mereka mengunakan data GFS sebagai analisis dan evaluasi kebijakan fiskal, tetapi dengan catatan bahwa kualitas data harus ditingkatkan. Kalau tidak ditingkatkan, secara alamiah tidak akan digunakan jika datanya tidak memenuhi syarat reliabilitas, kredibilitas, dan validitas. Dalam membuat kebijakan harus dengan data yang lengkap, kredibel, dan tidak hanya berasal dari satu sumber yang terlalu berisiko karena datanya mencangkup nasional dan mempunyai dampak internasional.

Kendala-kendala yang dihadapi organisasi $\mathrm{DJPb}$ dalam implementasi GFS tersebut adalah sebagai berikut:

a. Sumber daya manusia

Sumber daya manusia merupakan hal utama yang memerlukan perhatian dalam sebuah perencanaan strategis organisasi. Sumber daya manusia dalam implementasi GFS ini adalah sumber daya manusia di Kanwil DJPb terutama pada Seksi Analisa, Statistik, dan Penyusunan Laporan Keuangan. Penelitian ini memotret sumber daya manusia hanya sebatas pada Kanwil DJPb Provinsi DKI Jakarta sebagai penelitian awal dalam implementasi GFS. Sumber daya manusia pada Kantor Wilayah DJPb Provinsi DKI Jakarta dinilai kurang dalam melaksanakan tugas dan fungsinya sebagai kontributor data, terutama data
LKPD. Pernyataan tersebut didukung dengan informasi dari informan FRM-1 bahwa hal pertama yang menjadi kendala adalah SDM. SDM pada saat itu yang paling bagus ada di KPPN daripada di kanwil, akan tetapi untuk menyusun Laporan GFS di kanwil SDM diplanning dengan menempatkan SDM yang bagus.

Pernyatan tersebut diperkuat dengan pernyataan CMP-2 bahwa SDM di kanwil adalah kurang. Di antara tujuh staf, lima diantaranya berusia 55 tahun dengan kompetensi dasar $M s$ Word padahal yang diperlukan adalah kompetensi dasar Ms Excell.

\section{b. Deadline}

Tugas dan fungsi Seksi Analisa, Statistik, dan Penyusunan Laporan Keuangan tidak hanya menyusun laporan GFS saja tetapi juga menyusun Laporan Kuasa BUN tingkat Wilayah. Dalam penyusunan laporan GFS, mengalami kendala deadline penyusunan yang harus segera disampaikan ke Direktorat APK dalam jangka waktu yang telah ditentukan. Dalam menyusun laporan GFS di tingkat wilayah perlu adanya ketersediaan data LKPD dari pemerintah daerah di wilayah kerjanya. Pemerintah daerah dalam wilayah kerja Kanwil DJPb Provinsi DKI Jakarta hanya satu entitas pelaporan yaitu Pemerintah Provinsi DKI Jakarta. Akan tetapi, proses penyusunan LKPD lebih lama daripada penyusunan laporan GFS, hal tersebut mengakibatkan adanya kesulitan memperoleh data tepat waktu. Keterlambatan penyelesaian LKPD beserta metadata mengakibatkan terjadi keterlambatan penyampaian data dan kualitas data pemerintah daerah yang tidak valid. Dengan demikian, hasil konsolidasi laporan sering tidak lengkap. Data yang tidak diperoleh secara keseluruhan mengakibatkan laporan GFS yang tersusun menjadi informasi parsial dan dipertanyakan validitasnya. Pernyataan tersebut diperjelas dengan informasi langsung dari informan CMP-2 bahwa masalah time lag penyusunan laporan GFS dengan penyusunan laporan Pemda sering tidak sinkron. Penyusunan GFS lebih dulu daripada penyusunan laporan Pemda, sementara Pemda jika akan memberikan data harus di audit dulu oleh pengawas internal mereka. Jadi dalam penyusunan Laporan GFS kanwil masih memakai angka prediksi yang menjadi tidak valid terutama untuk triwulanan.

\section{c. Sistem informasi}

Sistem informasi menjadi salah satu isu yang paling mendominasi hambatan dalam implementasi GFS di Indonesia, ketersediaan data yang terintegrasi antara pemerintah pusat dan pemerintah daerah menjadi hal yang memerlukan penyempurnaan. Kurang optimalnya pemanfaatan aplikasi akuntansi berbasis teknologi informasi dan belum seragamnya penggunaan 
aplikasi sistem informasi akuntansi seperti SIPKD, SIMDA, dan lainnya sehingga menjadi hambatan untuk konsolidasi laporan GFS tingkat nasional. Walaupun pada saat penelitian ini disusun sedang dikembangkan Sistem Informasi Republik Indonesia (SIRI) yang mengintegrasikan informasi pemerintah pusat dan pemerintah daerah. SIRI yang sedang disusun ini menurut informasi CMP-1 baru bisa direalisasikan pada tahun 2020. Rencana untuk mengembangkan Sistem Informasi Keuangan Republik Indonesia untuk solusi bahwa saat ini masih menyusun manual dengan Ms Excell. Dengan SIRI, data SIKD bisa langsung terproses sehingga bisa menghasilkan laporan-laporan yang dibutuhkan dan teknik-teknik yang klerikal dapat dihilangkan. Hal tersebut membantu dalam fokus analisis data dan penggunaan data.

\section{KESIMPULAN DAN SARAN}

Hasil penelitian dari studi dokumentasi dan wawancara yang kemudian dianalisis menggunakan teknik intrepretatif menyimpulkan bahwa organisasi secara umum mengalami tekanan-tekanan institusional dengan menunjukkan gejala normative pressure, mimetic pressure, dan coersive pressure. Jenis tekanan institusional yang mendominasi implementasi Government Finance Statistics di Indonesia adalah normative pressure dan coersive pressure. Dominasi tersebut menunjukkan bahwa penggunaan informasi GFS untuk analisis dan evaluasi kebijakan fiskal di Indonesia belum memenuhi ekspektasi yang diinginkan. Tidak terpenuhinya ekspektasi tujuan awal implementasi GFS secara normatif tersebut terkait dengan adanya coersive pressure. Beberapa coersive pressure berpengaruh pada implementasi GFS yang dilaksanakan organisasi tidak hanya berfokus pada kebutuhan internal Kementerian Keuangan dalam hal ini Badan Kebijakan Fiskal.

Tekanan institusional berupa coersive pressure, mimetic pressure dan normative pressure dalam implementasi GFS di Indonesia mendapatkan respon dari organisasi $\mathrm{DJPb}$ Organisasi menghadapi kendala dalam merespon tekanantekanan institusional. Untuk meminimalisasi kendala tersebut saran untuk organisasi adalah perlunya meningkatkan kapasitas SDM yang menguasai akuntansi dan teknologi informasi dalam jumlah yang memadai, peningkatan kompetensi tenaga akuntansi yang menangani pengelolaan keuangan daerah dan menguasai basis akuntansi akrual, komitmen aparatur pemerintah pusat dan pemerintah daerah dalam upaya peningkatan akuntabilitas pengelolaan keuangan.

Dari sisi teknis juga perlu dilakukan pengembangan teknologi khususnya aplikasi penatausahaan dan akuntansi yang mengakomodasi basis akrual dan yang terintegrasi antara informasi akuntansi pemerintah pusat dan pemerintah daerah untuk mempermudah konsolidasi Laporan Government Finance Statistics, memperbaiki petunjuk teknis yang berkaitan dengan deadline penyusunan laporan GFS tingkat wilayah sehingga data yang disampaikan merupakan data yang valid. Komitmen pimpinan dan pejabat termasuk di dalamnya dukungan politik dari kepala daerah dan DPRD juga diperlukan untuk merealisasikan pengembangkan basis data pengelolaan data keuangan pusat dan daerah yang terintegrasi.

\section{IMPLIKASI DAN KETERBATASAN}

Penulis menyadari bahwa dalam penelitian ini masih terdapat banyak kekurangan. Kekurangan tersebut tidak lain karena keterbatasan penelitian dalam penyusunannya. Keterbatasan berupa kelengkapan data berupa statistik laporan-laporan GFS yang belum sepenuhnya diakses. Selain itu, keterbatasan pada narasumber yang terlibat langsung dalam implementasi GFS baik perumus kebijakan pada waktu GFS pertama kali muncul pada Undang-Undang Nomor 1 Tahun 2004, maupun penyusun di seluruh Kantor Wilayah DJPb. Informasi dari Badan Kebijakan Fiskal belum dapat merepresentasikan posisi GFS dengan jelas sebagai analisis dan evaluasi kebijakan fiskal juga menjadi keterbatasan penelitian ini. Keterbatasanketerbatasan itu menjadi beberapa kondisi yang dipertimbangkan dalam penelitian ini.

Penelitian ini adalah penelitian awal terkait implementasi GFS di Indonesia menggunakan Teori Institusional-Isomophism. Untuk keperluan penelitian selanjutnya saran-saran dari penulis diantaranya adalah menggunakan lingkup organisasi yang lebih luas yang melibatkan seluruh Kantor Wilayah DJPb di Indonesia sebagai objek penelitian untuk mendapatkan informasi yang lebih komprehensif, menggali informasi dari pembuat kebijakan yang terlibat langsung di awal implementasi GFS di Indonesia sebagai narasumber. Narasumber tersebut adalah pihak yang berada pada posisi jabatan dan kedudukan pengambil kebijakan ketika kebijakan implementasi GFS itu dibuat, menggali informasi dari informan yang terlibat dalam tim pembuat Undang-Undang Nomor 1 tahun 2004. Informan ini adalah pembuat kebijakan atau inisiator dibuatnya undang undang tersebut, selain itu menggunakan sumber data statistik deskriptif dengan menganalisis laporan-laporan GFS secara lebih mendetail untuk mendapatkan informasi substansi laporan GFS dalam evaluasi dan analisis kebijakan fiskal, dan menggunakan metode penelitian mix methods dengan mengolah data kuantitatif dan kualitatif untuk mendapatkan hasil penelitian yang lebih terukur. 


\section{PENGHARGAAN}

Penulis menyampaikan ucapan terima kasih kepada para pihak yang telah memberikan kontribusi berupa sumbang saran dan kontribusi lainnya terhadap penyelesaian penulisan penelitian ini yang tidak dapat disebutkan satu per satu. Ucapan terima kasih kepada pembimbing penulis Bapak Acwin Hendra Saputra yang membimbing dari awal dalam penulisan ini. Segala isi, pemikiran, dan hasil penelitian yang terdapat dalam penelitian ini adalah sepenuhnya tanggung jawab penulis termasuk error yang kemungkinan terjadi. Hasil penelitian bukan merupakan representasi dari organisasi di mana penulis berasal.

\section{DAFTAR PUSTAKA}

Akbar, Rusdi. (2012). Institusional Isomorphism dalam Akuntabilitas Kinerja Sektor Publik di Indonesia. http://feb.ugm.ac.id/id/riset-danpublikasi/artikel-dosen/1185-institutionalisomorphism-dalam-akuntabilitas-kinerjasektor-publik-di-indonesia.html (diakses 15 Desember 2016).

Amirya, Mirna., Ali Djamhuri, dan Unti Ludigdo. (2012). Pengembangan Sistem Anggaran dan Akuntansi Badan Layanan Umum Universitas Brawijaya: Perspektif Institusionalis. Jurnal Akuntansi Multiparadigma 3 Vol 3: 334-501.

Barton, Allan. (2011). Why Governments Should Use the Government Finance Statistics Accounting System. ABACUS Vol 47 No 4: 411:445.

Creswell, Jhon W. (2009). Research Design: Qualitative, Quantitative, and Mixed Methods Approaches. California: SAGE Publication.

2014. Penelitian Kualitatif dan Desain Riset: Memilih di antara lima pendekatan Edisi 3. Yogyakarta: Pustaka Pelajar.

Darono, Agung. (2012). Penggunaan Teori Institusional dalam Penelitian Teknologi Informasi dan Komunikasi di Indonesia. Seminar Nasional Aplikasi Teknologi Informasi. https://www.researchgate.net/publication/3 05477957 (diakses 18 Desember 2016).

------. 2016. Information Integration in Public Finance Management: An Institutional Politic Perpective. Jakarta: IRSA.

Darono, Agung., Lukito Edi Nugroho, dan Warsun Najib. (2013). Tinjauan Intrepretatif Terhadap Aspek-Aspek Institusional dalam Implementasi Layanan Elektronik: Studi Kasus PT. XYZ. JNTETI Vol 2: $29-36$.

DiMaggio, Paul J., dan W.W. Powell. (1983). The Iron Cage Revisited: Institutional
Isomorphism and Collective Rationality in Organizational Fields. American Sociological Review Vol 48: 147-160.

Direktorat Jenderal Perbendaharaan. (2015a). Delapan Rekomendasi untuk Pemerintah Dalam Perbaikan Pengelolaan Keuangan Negara dan Kualitas LKPP. http://www.djpbn.kemenkeu.go.id/portal/id /berita/129-nasional/1772-delapanrekomendasi-untuk-pemerintah-dalamrangka-perbaikan-pengelolaan-keuangannegara-dan-peningkatan-kualitas-

lkpp.html?highlight=WyJnb3Zlcm5tZW50Iiwi ZmluYW5jZSIsInN0YXRpc3RpY3MiLCJnb3Zlc m5tZW50IGZpbmFuY2UiLCJnb3Zlcm5tZW50I GZpbmFuY2Ugc3RhdGlzdGljcyIsImZpbmFuY2 Ugc3RhdGlzdGljcyJd (diakses 23 Desember 2016).

------. (2015b). Jawa Barat Sinergikan Entitas Akuntansi Untuk Opini WTP. http://www.djpbn.kemenkeu.go.id/portal/id /berita/128-regional/1704-jawa-baratsinergikan-entitas-akuntansi-untuk-opiniwtp.html?highlight=WyJnZnMiXQ== (diakses 23 Desember 2016).

(2016). GFS: Lebih dari Sekedar Laporan Konsolidasian.

http://www.djpbn.kemenkeu.go.id/portal/id /berita/berita/berita-nasional/2406-gfslebih-dari-sekedar-laporankonsolidasian.html?highlight=WyJnZnMiXQ== (diakses 23 Desember 2016).

Djamhuri, A. dan Mahmudi. (2006). New Public Management, Accounting Reform, and Institutional Perspective of Public Sector Accounting in Indonesia. Jakarta: Jurnal Bisnis dan Akuntansi Vol 8: 3.

Dziobek, Caludia. (2013). Recent Improvements to the Government Finance Statistics Yearbook Database in Response to Analytical Needs. IMF Working Paper: International Monetary Fund.

Frumkin, Peter., dan Joseph Galaskiewicz. Institutional Isomorphism and Public Sector Organization. Journal of Public Administration Theory.

Fuad, Noor., Subkhan, dan Insyafiah. (2006). Government Finance Statistics beserta Ilustrasi Penerapannya di Indonesia. Jakarta: LPKPAP.

Guba, Egon G., dan Yvonna S. Lincoln. (1994). Competing Paradigms in Qualitative Research, dalam Norman K. Denzim and Yvonna S. Lincoln. Handbook of Qualitative Research. California: Sage Publications.

International Monetary Fund. (2005). Indonesia: Report on the Observance of Standards and 
Codes-Data Module, Response by the Authorities, and Detailed Assessments Using the Data Quality Assessment Framework. Washington, DC: International Monetary Fund.

http://www.imf.org/external/pubs/ft/scr/20 05/cr05255.pdf (diakses 26 Desember 2016).

-. (2010). Government Finance Statistics to Streghten Fiscal Analysis. Washington, DC: International Monetary Fund.

. (2013). Review of the Implementastion of Government Finance Statistics to Strenghtehen Fiscal Analysis. Washington, DC: International Monetary Fund.

Johnston, Mel. (2013). Mimetic, Coersive and Normative Influence and the Decision of National Sport Organisation to Bid for World Championship Events. Auckland: Auckland University of Technology.

Kementerian Keuangan, Bank Indonesia, dan Badan Pusat Statistik. (2014). The Past Five Years of G20 DGI Implementation in Indonesia.

http://www.imf.org/external/np/seminars/e ng/2014/dgi/pdf/e.pdf (diakses 26 Desember 2016).

Kementerian Keuangan. (2011a). Indonesia Bisa Jadi Inspirasi Dalam Pelaporan Keuangan Negara Dan Akuntansi. http://kemenkeu.go.id/Berita/indonesiabisa-jadi-inspirasi-dalam-pelaporankeuangan-negara-dan-akuntansi (diakses 23 Desember 2016).

-----. (2011b). Pemerintah Terus Tingkatkan Kapasitas Pelaporan Keuangan dan Akuntansi. http://kemenkeu.go.id/Berita/pemerintahterus-tingkatkan-kapasitas-pelaporankeuangan-dan-akuntansi (diakses Desember 2016).

(2013). ASEAN dan Australia Sharing Penerapan Statistik Keuangan Pemerintah di Indonesia.

http://kemenkeu.go.id/Berita/asean-danaustralia-sharing-penerapan-statistikkeuangan-pemerintah-di-indonesia (diakses 20 Desember 2016).

----- (2014). Ditjen Perbendaharaan Siap Hadapi Tiga Agenda Besar 2014. http://kemenkeu.go.id/Berita/ditjenperbendaharaan-siap-hadapi-tiga-agendabesar-2014 (diakses 23 Desember 2016).

(2016). BPPK Selenggarakan Lokakarya SIRI dan Diklat GFS. http://kemenkeu.go.id/BeritaUnit/bppk-selenggarakan-lokakarya-siri-dandiklat-gfs (diakses 20 Desember 2016).
Madjid, Noor Cholis. (2014). Asumsi Dasar Ekonomi Makro, Langkah Awal Penyusunan APBN yang Berkualitas. Majalah Edukasi Edisi 20 hal 3235. Jakarta: BPPK.

Mankiw, N. Gregory. (2011). Brief Principles of Macroeconomics. 6th edition. South Western Cengage Learning. http://libgen.in/book/index.php?md5=5d4af deaf416511021b5c7e6ce439a73 (diakses 16 November 2016).

Miles, M.B., dan Huberman, A. M. (1994). Qualitative Data Analysis. California: SAGE Publication.Inc.

Musgrave, Richard A. (1959). The Theory of Public Finance: A Study in Public Economy. New York: McGraw-Hill.

Musgrave, Richard A., Peggy B. Musgrave. (1991). Keuangan Negara dalam Teori dan Praktek. Jakarta: Erlangga.

Nasution, Mulia P. (2004). Sistem Akuntansi Pemerintahan. Makalah. Jakarta: Kementerian Keuangan.

Nazir, Moh. (2014). Metode Penelitian. Jakarta: Ghalia Indonesia.

Scott, W.R. (2004). Institutional Theory: Contributing to a Theoritical Research Program, in K.G. Smith, dan M.A. Hitt (Eds.): Great Minds in Management: The Process of Theory Development. Oxford: Oxford University Press.

(2001). Institutions and Organizations. Thousand Oaks, California: SAGE Publishing.

Sugiyono. (2014). Metode Penelitian Kuantitatif, Kualitatif, dan $R \& D$. Bandung: Alfabeta.

Sukirno, Sadono. (2004). Makroekonomi Teori Pengantar Edisi Ketiga. Jakarta: PT Rajagrafindo Persada.

Tanzi, Vito. (1991). Public Finance in Developing Countries. Aldershot: Edwar Edgar.

-----. (2014). Budget, Institutions and Fiscal Policy. Fiscal Policy Meeting Ministry of Finance and Getulio Vargas Foundation. Sao Paulo.

Thornton, P.H., dan W. Ocasio. (2008). Institutional Logics, in C.O. Royston Greenwood, Roy Suddaby, Kerstin Sahlin-Andersson (Ed.): The Sage Handbook of Organizational Institutionalism. Sage Publications.

Uppal, J.S dan M. Suparmoko. (1986). Intergovernmental Finance in Indonesia. Jurnal Ekonomi Keuangan Indonesia Volume XXXIV, No.4: 45-54. 
Wahyuni, Tri Ersa. (2012). Discussion on Indonesia-IFRS Convergence. http://ersatriwahyuni.blogspot.co.id/2012/0 9/the-use-of-institutional-theory-in-ifrs.html (diakses 15 Desember 2016).

Wanitthanankun, Jarupan. (2014). Government Finance Statistics for Fiscal Transparency and Sustainability: A Case Study of Thailand. Bangkok: Bank of Thailand.

Weber, Kristen. dan Sarah Morrison. (2015). The Institutional Analysis: Uncovering Pathways to Improving Public Systems and Intervention for Children and Families. Washington, DC: Center for the Study of Social Policy.

Wiest, Benoit. dan Pokar Khemani. (2007). How to Check Integrity of Fiscal Data. http://blogpfm.imf.org/pfmblog/2016/11/how-tocheck-integrity-of-fiscal-data-.html (diakses 18 Desember 2016).

Wuryanto, Puput. (2015). Relevansi Penerapan Government Finance Statistics (GFS) dalam Menilai Kebijakan Fiskal. Jurnal BPPK Volume 8: 53-76. 


\section{Hasil Studi Intrepretasi Dokumentasi Publikasi Resmi Internasional}

\begin{tabular}{|c|c|c|}
\hline Waktu & Deskripsi Publikasi & Hasil Intrepretasi terkait Implementasi GFS \\
\hline $\begin{array}{l}\text { Juli } \\
2005\end{array}$ & $\begin{array}{l}\text { Report on the Observance of } \\
\text { Standards and Codes (ROSC)- } \\
\text { Data Module of Indonesia pada } \\
\text { tautan } \\
\text { http://www.imf.org/external/ } \\
\text { pubs/ft/scr/2005/cr05255.pd } \\
\underline{\mathrm{f}}\end{array}$ & $\begin{array}{l}\text { Implementasi GFS tercantum dalam rekomendasi IMF dengan } \\
\text { latar belakang bahwa statistik keuangan merupakan mandat } \\
\text { dari UU Nomor } 1 \text { 2004 yang harus dilaksanakan dan } \\
\text { dipublikasikan pada website resmi Kementerian Keuangan. } \\
\text { Menunjukkan gejala coersive pressure. }\end{array}$ \\
\hline $\begin{array}{l}\text { Juni } \\
2014\end{array}$ & $\begin{array}{l}\text { Publikasi seminar The Joint } \\
\text { FSB/IMNF Global Conference di } \\
\text { Basel, Switzerland tanggal 25- } \\
\text { 26 Juni 2014 dengan judul The } \\
\text { Past Five Years of G20 DGI } \\
\text { Implementation in Indonesia } \\
\text { padartautan } \\
\underline{\text { http://www.imf.org/external/ }} \\
\underline{\mathrm{np} / \mathrm{seminars} / \mathrm{eng} / 2014 / \mathrm{dgi} / \mathrm{p}} \\
\mathrm{df} / \mathrm{e.pdf}\end{array}$ & $\begin{array}{l}\text { Rekomendasi ke-15 dan rekomendasi ke-17 menyebutkan } \\
\text { bahwa dalam implementasi DGI terkait dengan Sectoral } \\
\text { Account sebagai salah satu langkahnya adalah implementasi } \\
\text { GFSM } 2014 \text { oleh Kementerian Keuangan. Menunjukkan gejala } \\
\text { coersive pressure. }\end{array}$ \\
\hline
\end{tabular}

Sumber: Diolah dari berbagai sumber 


\section{Hasil Studi Intrepretasi Dokumentasi Publikasi Resmi Nasional}

\begin{tabular}{|c|c|c|}
\hline Waktu & Deskripsi Publikasi & Hasil Intrepretasi terkait Implementasi GFS \\
\hline $\begin{array}{l}\text { Agustus } \\
2015\end{array}$ & $\begin{array}{l}\text { Rencana Strategis Direktorat Jenderal } \\
\text { Perbendaharaan tahun 2015-2019 pada } \\
\text { tautan } \\
\text { http://www.djpbn.kemenkeu.go.id/publi } \\
\text { kasi/ppid/i c renstra djpbn.pdf }\end{array}$ & $\begin{array}{l}\text { Penyempurnaan Laporan Statistik Keuangan } \\
\text { Pemerintah Indonesia melalui sistem Information } \\
\text { Technology yang terintegrasi antara akuntansi } \\
\text { pusat dan daerah. Menunjukkan adanya respon } \\
\text { organisasi dalam menghadapi normative pressure. }\end{array}$ \\
\hline $\begin{array}{l}\text { September } \\
2011\end{array}$ & $\begin{array}{l}\text { Indonesia bisa menjadi inspirasi dunia } \\
\text { dalam pelaporan keuangan pada tautan } \\
\text { berita } \\
\text { http://kemenkeu.go.id/Berita/indonesia } \\
\text {-bisa-jadi-inspirasi-dalam-pelaporan- } \\
\text { keuangan-negara-dan-akuntansi }\end{array}$ & $\begin{array}{l}\text { Kerjasama Kementerian Keuangan Indonesia } \\
\text { dengan Kementerian Keuangan Australia sejak } \\
2007 \quad \text { tentang peningkatan } \\
\text { kapasitas pelaporan keuangan negara dan } \\
\text { akuntansi termasuk didalamnya kerjasama dalam } \\
\text { implementasi GFS. Menunjukkan adanya respon } \\
\text { organisasi dalam menghadapi mimetic pressure. }\end{array}$ \\
\hline $\begin{array}{l}\text { September } \\
2011\end{array}$ & $\begin{array}{l}\text { Migrasi SAP CTA menuju Accrual pada } \\
\text { tautan berita } \\
\text { http://kemenkeu.go.id/Berita/pemerinta } \\
\underline{\text { h-terus-tingkatkan-kapasitas-pelaporan- }} \\
\text { keuangan-dan-akuntansi }\end{array}$ & $\begin{array}{l}\text { Reformasi pengelolaan keuangan negara di } \\
\text { Indonesia yang terjadi di DJPb mengacu pada } \\
\text { international best practices. Penggunaan standar } \\
\text { akuntansi akrual merupakan langkah nyata dalam } \\
\text { reformasi pengelolaan keuangan. Menunjukkan } \\
\text { adanya respon organisasi dalam menghadapi } \\
\text { gejala mimetic pressure. }\end{array}$ \\
\hline $\begin{array}{l}\text { Oktober } \\
2013\end{array}$ & $\begin{array}{l}\text { ASEAN dan Australia Sharing Penerapan } \\
\text { Statistik Keuangan Pemerintah di } \\
\text { Indonesia pada tautan berita } \\
\text { http://kemenkeu.go.id/Berita/asean- } \\
\text { dan-australia-sharing-penerapan- } \\
\underline{\text { statistik-keuangan-pemerintah-di- }} \\
\underline{\text { indonesia }}\end{array}$ & $\begin{array}{l}\text { Kerjasama antara Kementerian Keuangan dengan } \\
\text { IMF dan GPF diwujudkan dalam dilaksanakannya } \\
\text { Lokakarya GFS. Menunjukkan adanya gejala } \\
\text { mimetic pressure dan respon organisasi dalam } \\
\text { menghadapi tekanan institusional tersebut. }\end{array}$ \\
\hline $\begin{array}{l}\text { Januari } \\
2014\end{array}$ & $\begin{array}{l}\begin{array}{l}\text { Agenda besar DJPb tahun } 2014 \text { pada } \\
\text { tautan berita }\end{array} \\
\text { http://kemenkeu.go.id/Berita/ditjen- } \\
\text { perbendaharaan-siap-hadapi-tiga- } \\
\text { agenda-besar-2014 }\end{array}$ & $\begin{array}{l}\text { Implementasi GFS menjadi agenda besar kedua } \\
\text { yang dilakukan DJPb dengan bekerja sama } \\
\text { dengan para stakeholders. Menunjukkan adanya } \\
\text { respon organisasi dalam menghadapi gejala } \\
\text { normative pressure. }\end{array}$ \\
\hline Juni 2015 & $\begin{array}{l}\begin{array}{l}\text { Sinergi Entitas Pelaporan Keuangan pada } \\
\text { tautan berita }\end{array} \\
\text { http://www.djpbn.kemenkeu.go.id/porta } \\
\text { l/id/berita/128-regional/1704-jawa- } \\
\underline{\text { barat-sinergikan-entitas-akuntansi- }} \\
\underline{\text { untuk-opini- }} \\
\underline{\text { wtp.html?highlight=WyJnZnMiXQ== }}\end{array}$ & $\begin{array}{l}\text { Implementasi Sistem Akuntansi Berbasis Akrual } \\
\text { pada pemerintah daerah untuk konsolidasian } \\
\text { data statistik keuangan pemerintah. } \\
\text { Menunjukkan adanya respon organisasi dalam } \\
\text { menghadapi gejala mimetic pressure }\end{array}$ \\
\hline $\begin{array}{l}\text { Agustus } \\
2015\end{array}$ & $\begin{array}{l}\text { Rekomendasi Badan Anggaran DPR RI } \\
\text { kepada pemerintah dalam perbaikan } \\
\text { pengelolaan keuangan pada tautan berita } \\
\text { http://www.djpbn.kemenkeu.go.id/porta } \\
\underline{\text { l/id/berita/129-nasional/1772-delapan- }} \\
\underline{\text { rekomendasi-untuk-pemerintah-dalam- }} \\
\underline{\text { rangka-perbaikan-pengelolaan- }} \\
\underline{\text { keuangan-negara-dan-peningkatan- }} \\
\underline{\text { kualitas- }} \\
\underline{\text { lkpp.html?highlight=WyInb3Zlcm5tZW5 }} \\
\underline{\text { 0IiwiZmluYW5jZSIsInN0YXRpc3RpY3Mi }} \\
\underline{\text { LCInb3Zlcm5tZW50IGZpbmFuY2UiLCJnb }} \\
\underline{\text { 3Zlcm5tZW50IGZpbmFuY2Ugc3RhdGlzd }} \\
\underline{\text { GljcyIsImZpbmFuY2Ugc3RhdGlzdGljcyId }}\end{array}$ & $\begin{array}{l}\text { Rekomendasi ke-6 menyebutkan bahwa } \\
\text { pemerintah agar menerapkan dan menyusun } \\
\text { statistik keuangan pemerintah (Government } \\
\text { Finance Statistics). Menunjukkan adanya gejala } \\
\text { coersive pressure. }\end{array}$ \\
\hline
\end{tabular}




\begin{tabular}{|c|c|c|}
\hline Waktu & Deskripsi Publikasi & Hasil Intrepretasi terkait Implementasi GFS \\
\hline $\begin{array}{l}\text { Januari } \\
2016\end{array}$ & $\begin{array}{l}\text { Launching Website GFS pada tautan } \\
\text { berita } \\
\underline{\text { http://www.djpbn.kemenkeu.go.id/porta }} \\
\text { l/id/berita/berita/berita-nasional/2406- } \\
\text { gfs-lebih-dari-sekedar-laporan- } \\
\underline{\text { konsolidasian.html?highlight=WyJnZnMi }} \\
\underline{\mathrm{XQ}==}\end{array}$ & $\begin{array}{l}\text { Keterbukaan data publikasi tampil pada menu } \\
\text { utama website resmi Direktorat Jenderal } \\
\text { Perbendaharaan www.gfs.djpbn.kemenkeu.go.id } \\
\text { Menunjukkan adanya respon organisasi dalam } \\
\text { menghadapi gejala coersive pressure. }\end{array}$ \\
\hline $\begin{array}{l}\text { Agustus } \\
2016\end{array}$ & $\begin{array}{l}\begin{array}{l}\text { Penyelenggaraan Diklat GFS oleh } \\
\text { pada tautan }\end{array} \\
\text { http://kemenkeu.go.id/Berita- } \\
\text { Unit/bppk-selenggarakan-lokakarya-siri- } \\
\text { dan-diklat-gfs }\end{array}$ & $\begin{array}{l}\text { Narasumber pada Diklat GFS berasal dari IMF, } \\
\text { DJPb dan DJPPR sebagai praktisi langsung } \\
\text { implementasi GFS. Menunjukkan adanya respon } \\
\text { organisasi dalam menghadapi gejala mimetic } \\
\text { pressure. }\end{array}$ \\
\hline
\end{tabular}

Sumber: Diolah dari berbagai sumber 